San Jose State University

SJSU ScholarWorks

Master's Theses

Master's Theses and Graduate Research

1994

\title{
The hydrogeology of Doall Ravine and northern portions of Elk Ravine Lawrence Livermore National Laboratory Site 300
}

William Robert Dugan

San Jose State University

Follow this and additional works at: https://scholarworks.sjsu.edu/etd_theses

\section{Recommended Citation}

Dugan, William Robert, "The hydrogeology of Doall Ravine and northern portions of Elk Ravine Lawrence Livermore National Laboratory Site 300" (1994). Master's Theses. 747.

DOI: https://doi.org/10.31979/etd.nf8f-kbrs

https://scholarworks.sjsu.edu/etd_theses/747

This Thesis is brought to you for free and open access by the Master's Theses and Graduate Research at SJSU ScholarWorks. It has been accepted for inclusion in Master's Theses by an authorized administrator of SJSU ScholarWorks. For more information, please contact scholarworks@sjsu.edu. 


\section{INFORMATION TO USERS}

This manuscript has been reproduced from the microfilm master. UMI films the text directly from the original or copy submitted. Thus, some thesis and dissertation copies are in typewriter face, while others may be from any type of computer printer.

The quality of this reproduction is dependent upon the quality of the copy submitted. Broken or indistinct print, colored or poor quality illustrations and photographs, print bleedthrough, substandard margins, and improper alignment can adversely affect reproduction.

In the unlikely event that the author did not send UMI a complete manuscript and there are missing pages, these will be noted. Also, if unauthorized copyright material had to be removed, a note will indicate the deletion.

Oversize materials (e.g., maps, drawings, charts) are reproduced by sectioning the original, beginning at the upper left-hand corner and continuing from left to right in equal sections with small overlaps. Each original is also photographed in one exposure and is included in reduced form at the back of the book.

Photographs included in the original manuscript bave been reproduced xerographically in this copy. Higher quality $6^{n} \times 9^{n}$ black and white photographic prints are available for any photographs or illustrations appearing in this copy for an additional charge. Contact UMI directly to order.

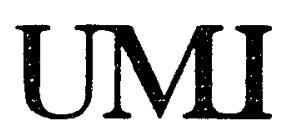



Order Number 1358171

The hydrogeology of Doall Ravine and northern portions of Elk Ravine, Lawrence Livermore National Laboratory Site 300

Dugan, William Robert, M.S.

San Jose State University, 1994

Copyright (C1994 by Dugan, William Robert. All rights reserved.

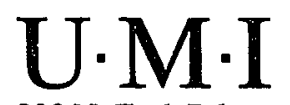

300 N. Zeeb Rd.

Ann Arbor, MI 48106 

THE HYDROGEOLOGY OF DOALL RAVINE

AND NORTHERN PORTIONS OF ELK RAVINE

LAWRENCE LIVERMORE NATIONAL LABORATORY

SITE 300

\author{
A Thesis \\ Presented to \\ The Faculty of the Department of Geology \\ San Jose State University
}

\author{
In Partial Fulfillment \\ of the Requirements for the Degree \\ Master of Science
}

By

William Robert Dugan

May, 1994 
(c) 1994

William Robert Dugan

ALL RIGHTS RESERVED 
APPROVED FOR THE DEPARTMENT OF GEOLOGY

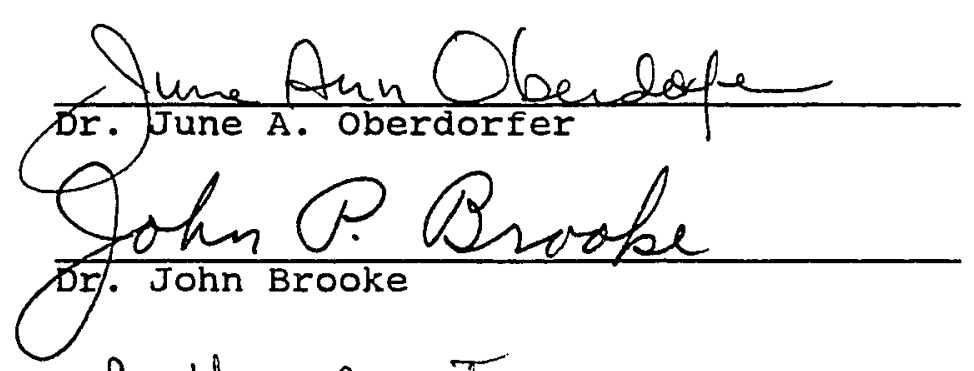

David W. Carpenter

Mr. David W. Carpenter

APPROVED FOR THE UNIVERSITY

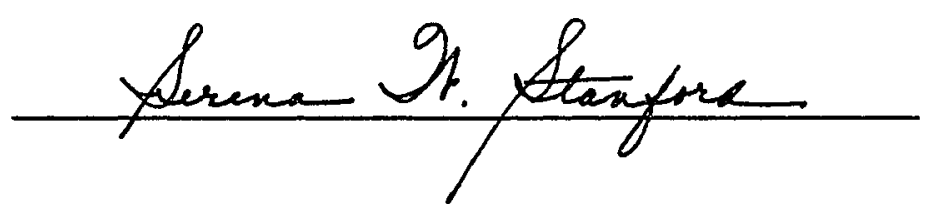




\section{ABSTRACT}

THE HYDROGEOLOGY OF DOALL RAVINE AND NORTHERN PORTIONS OF ELK RAVINE LAWRENCE LIVERMORE NATIONAL LABORATORY

SITE 300

\section{by William Robert Dugan}

Groundwater has been impacted with elevated tritium activities in north-central site 300 near Building 850 . The tritium plume has migrated approximately 1,800 feet eastsoutheastward through saturated alluvium and bedrock into the Elk Ravine near Pit 2. Of interest is whether faulting exists in the vicinity of Pit 2 , and, if present, whether it acts as a barrier or conduit to groundwater flow and tritium migration.

Methods used for this study included geologic mapping, the excavation and logging of exploratory trenches, and a review of available recorcs including tritium data and monitoring well logs.

Faulting was encountered and documented 200 feet west of Pit 2. In this area the fault appears to form a low permeability zone that allows the migration of groundwater and tritium, but with a very steep hydraulic gradient. stratigraphy and dips, rather than the fault, appear to have the greatest influence on the direction of groundwater migration. 


\section{ACKNOWLEDGEMENTS}

This study was funded by the Lawrence Livermore National Laboratory's (LLNL) Environmental Restoration Division (ERD). I would like to thank Fred Hoffman, ILNL ERD Division Leader, for providing the opportunity to perform this study, for his direction, and for his support. I also thank Albert Lammarre, LLNL ERD Site 300 Section Leader, for providing strong management and administrative support.

Dr. June oberdorfer and Dr. John Brooke, of San Jose State University, and David Carpenter of LLNL formed the thesis committee overseeing the study. I thank them for their supervision, constructive criticism, and patience.

I am indebted to Bob Mateik for his review of portions of this text. I also am indebted to Michael Taffet of LLNL for $\mathrm{his}$ technical and administrative support.

I thank Marion Heaton, John Gresci, and Carleen King of LLNL, and site 300 security for logistical support and access to site 300. Finally I thank Mark Meamber of LLNL, and Sandra Smith for their drafting support. 
TABLE OF CONTENTS

Page

ABSTRACT . . . . . . . . . . . . . . . . . iv

INTRODUCTION

Previous studies... . . . . . . . . . . . . . 4

Topography . . . . . . . . . . . . . . . . 5

Regional Geology . . . . . . . . . . . . 7

Northern Site 300 Geology . . . . . . . . . 10

Previous Hydrogeologic Interpretation . . . . . . 14

FIELD METHODS AND RESULTS . . . . . . . . . . . . . 16

Geologic Mapping . . . . . . . . . . . . 16

Methods . . . . . . . . . . . 16

Surface outcrops . . . . . . . . . . 16

Neroly Formation . . . . . . . . . 17

Alluvium and colluvium. . . . . . . 20

Structure... . . . . . . . . . 20

Folds . . . . . . . . . . . . 20

Faults... . . . . . . . . 23

Exploratory Trenches . . . . . . . . . . . . 24

HYDROGEOLOGIC EVALUATION . . . . . . . . . . . . . 29

Hydrogeologic Cross Section . . . . . . . . . 29

Identification of Water-occurrence Zones . . . . 31

Hydraulic Gradient . . . . . . . . . . . . 34 
TABLE OF CONTENTS

(Continued)

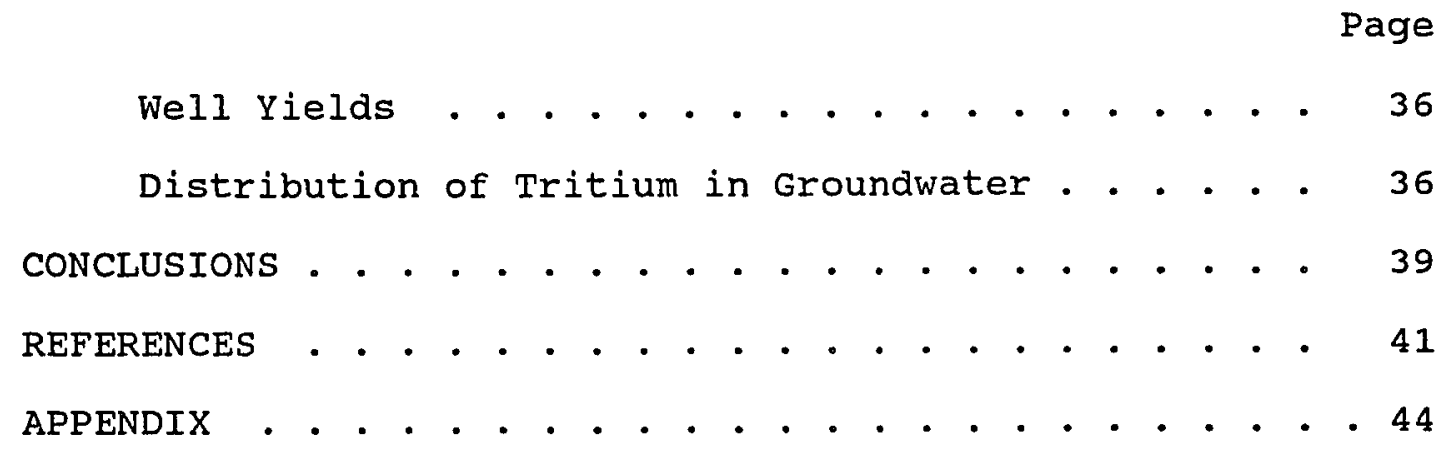




\section{LIST OF ILLUSTRATIONS}

Figure

Page

1 Location of site 300 and surrounding area . . 2

2 Planimetric map of site 300 . . . . . . . . 3

3 Topography, roads, landfills, and buildings of north-central site 300 . . . . . . . . . 6

4 Generalized geologic map of the San Francisco Bay area showing the location of Site 300

5 Map showing principal faults in the region surrounding site 300 . . . . . . . . . . . . 9

6 Map and cross section showing interpretations of geology of site 300 prior to this investigation . . . . . . . . . . . . . 11

7 Schematic diagram showing interpretations prior to this investigation of East Firing Area groundwater contours and the Building 850 groundwater tritium plume near Pit 2 . . . 15

8 Geologic map of eastern Doall Ravine and Pit 2 study area . . . . . . . . . . . . 18

9 Schematic map of mapped faults and folds within northern Site 300 . . . . . . . . 21

10 Locations of exploratory trenches in the eastern Doall Ravine - Pit 2 area . . . . . 25

11 Photograph of Neroly blue sandstone (Tnbs 1 ) faulted against. Neroly conglomerate (Tngl $l_{1}$ ) within trench TR-EFA-02 . . . . . . . . . 26

12 Photograph of trench TR-EFA-05 in the foreground and trench TR-EFA-02 in the background . . . . . . . . . . . . .

13 Hydrogeologic cross section $A-A^{\prime}$ illustrating the alluvium and shallow bedrock aquifer system, and the deeper bedrock aquifer system 


\section{LIST OF ILLUSTRATIONS}

(continued)

14 Groundwater elevation contour map

of the alluvium and shallow bedrock

aquifer system within the East and West

Firing Areas, May 1991 . . . . . . . . 35

15 Groundwater tritium activity contour

map for the alluvium and shallow

bedrock system within the East and West

Firing Areas, May 1991 . . . . . . . . 


\section{INTRODUCTION}

Site 300 is a high-explosives test area established by the Lawrence Livermore National Laboratory (LLNL) in 1955. It covers approximately 11 square miles in the Altamont Hills 15 miles east of Livermore and 8 miles west of Tracy, California (Figure 1).

Recent studies carried out by the Environmental Restoration and Earth Sciences Divisions of LLNL tentatively concluded that an inferred splay of the Elk Ravine Fault passes beneath inactive Pit 2 landfill in north-central site 300 (Figure 2). Of interest is whether this splay, if present, acts as a barrier or conduit to groundwater flow near the intersection of Doall and Elk Ravines. Groundwater in this area has been impacted by an upgradient tritium source. An assessment of surface exposures and shallow faulting is necessary to better establish the pathway of tritium plume migration in this area.

This thesis presents the results of geologic mapping in eastern Doall Ravine and in the vicinity of Pit 2, documents the emplacement and logging of several exploratory trenches across and near the suspected fault splay, and presents a hydrogeologic evaluation of shallow groundwater conditions beneath eastern Doall Ravine and Elk Ravine near Pit 2. 


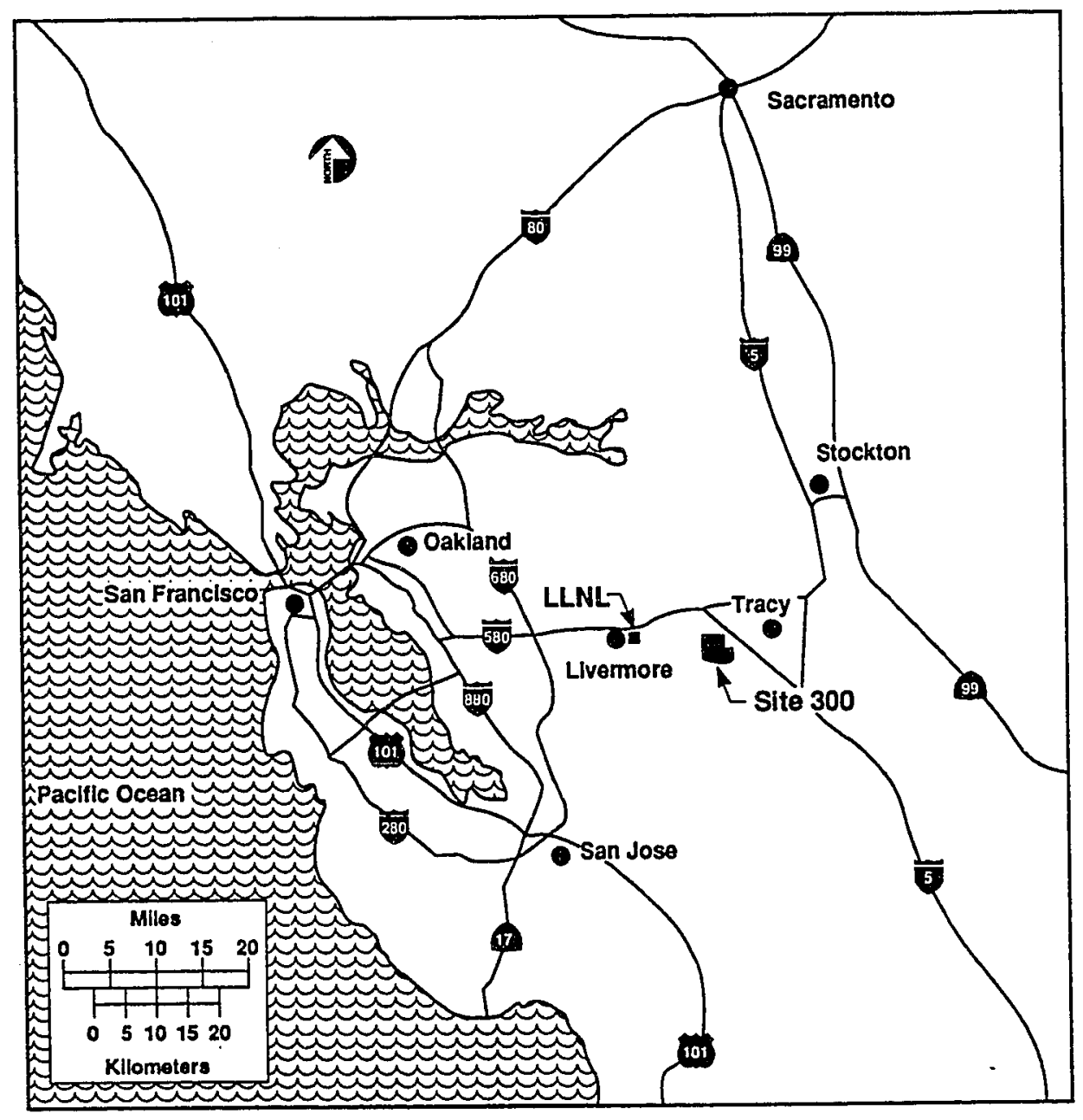

Figure 1. Locations of LLNL and Site 300. 


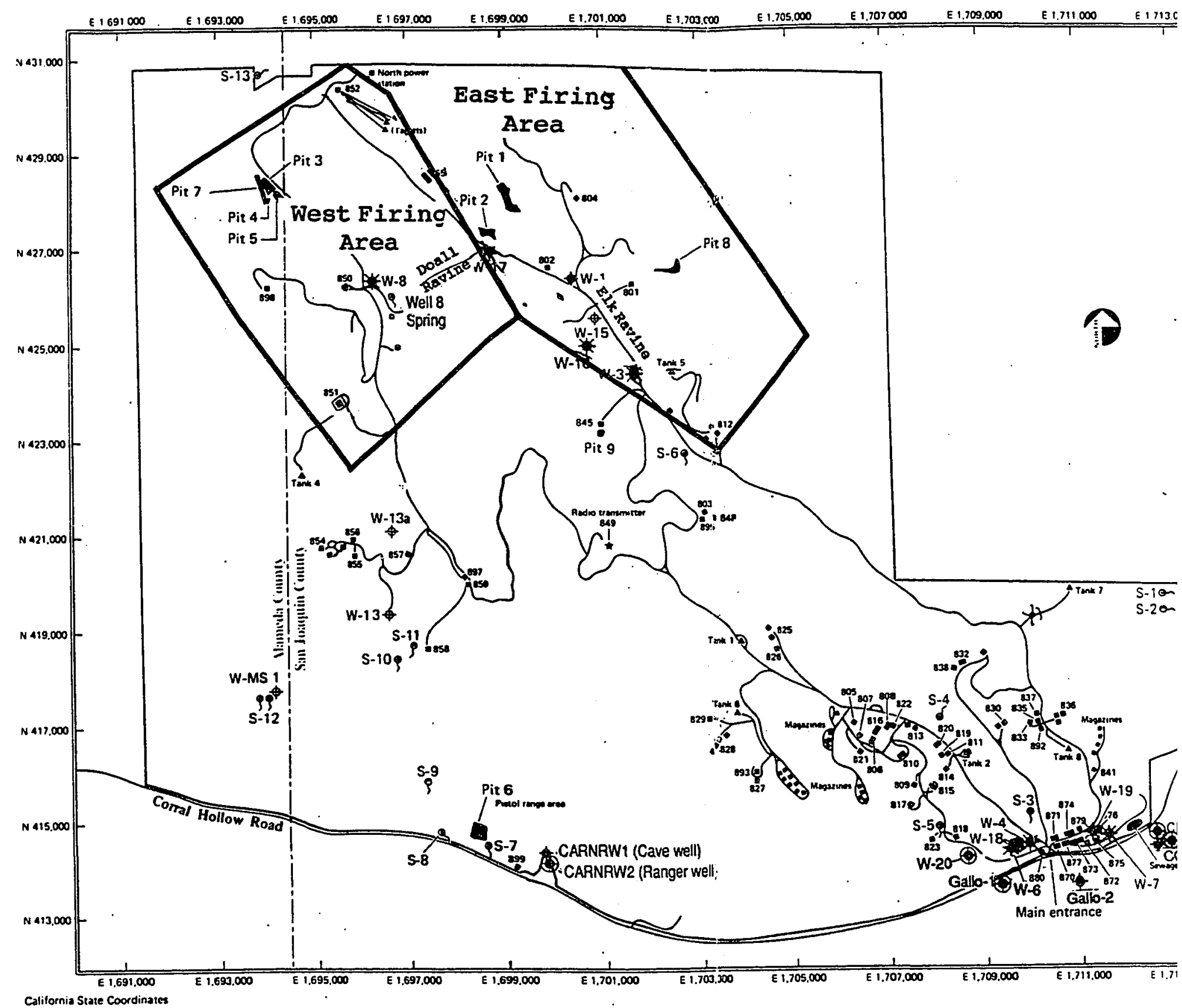

Figure 2. Planimetric map of Site 300 . 



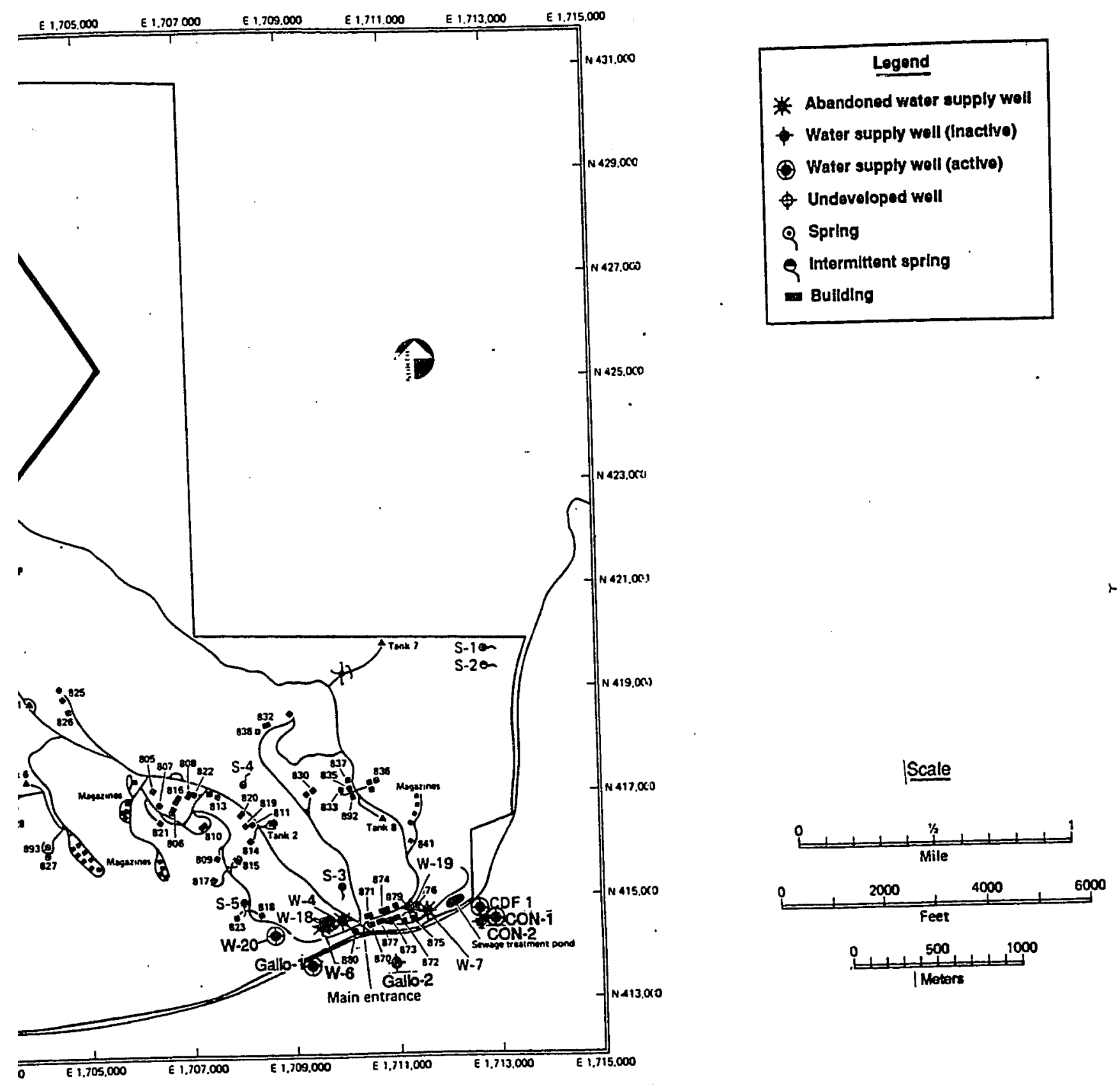




\section{Previous Studies}

The geology of the study area was first mapped by Huey (1948) in his study of the Tesla Quadrangle. The work of Huey was revised and modified by Dibblee (1980). Dibblee's work still serves as the most current published geologic map of the study area and for most of site 300 .

In 1983 two reports were published by LLNL as part of the Hazardous Waste Assessment Program (HWAP) conducted at Site 300 in 1982. The first report published (Raber and Carpenter, 1983) presented the results of a study of the geology, hydrogeology, and geochemistry of site 300 as related to eight on-site, solid waste, landfill pits. A second report published (Carpenter and Peifer, 1983) contains the borehole logs, well completion data, and chemical test results of groundwater from the 17 wells installed for the HWAP study.

In 1984 landfill monitoring wells adjacent to the Pit 7 Complex in northwestern site 300 revealed the presence of groundwater contaminated with tritium. These tritium levels were in excess of the state of California drinking water standard, 20,000 pico curies per liter $(p c i \backslash L)$. Over 50 boreholes were then drilled and completed into monitoring wells to characterize the local hydrogeology and tritium distribution. 
In December 1985 an extensive report (Buddmeier, 1985) was released presenting the results of all data collected through october 1985. The report identified the limits and contours of tritium concentrations in the first groundwaterbearing zone near inactive landfill Pits 3 and 5, from contaminated areas near Building 850 , and in a isolated area within eastern Doall Ravine. Between 1987 and 1991 LLNL published quarterly reports which included the results of groundwater elevations and tritium activities within the West firing Area (WFA) and East Firing Area (EFA).

In 1989 LLNL personnel published a Remedial Investigation and Feasibility study (RI\FS) Report for the tritium plume resulting from leakage from landfills within northwest site 300 (Taffet et al., 1989). A draft Remedial Investigation (RI) Report for the Building 850 tritium plume was published in 1990 (Taffet et al., 1990a). A draft Feasibility study (FS) Report for the Building 850 tritium plume was published in April 1990 (Taffet et al., 1990b) . Field notes, interpretations, and conclusions of this thesis were included as part of the RI and FS reports.

\section{Topography}

The center of the study area is the confluence of Doall Ravine and Elk Ravine (Figure 3). Steep slopes 300 


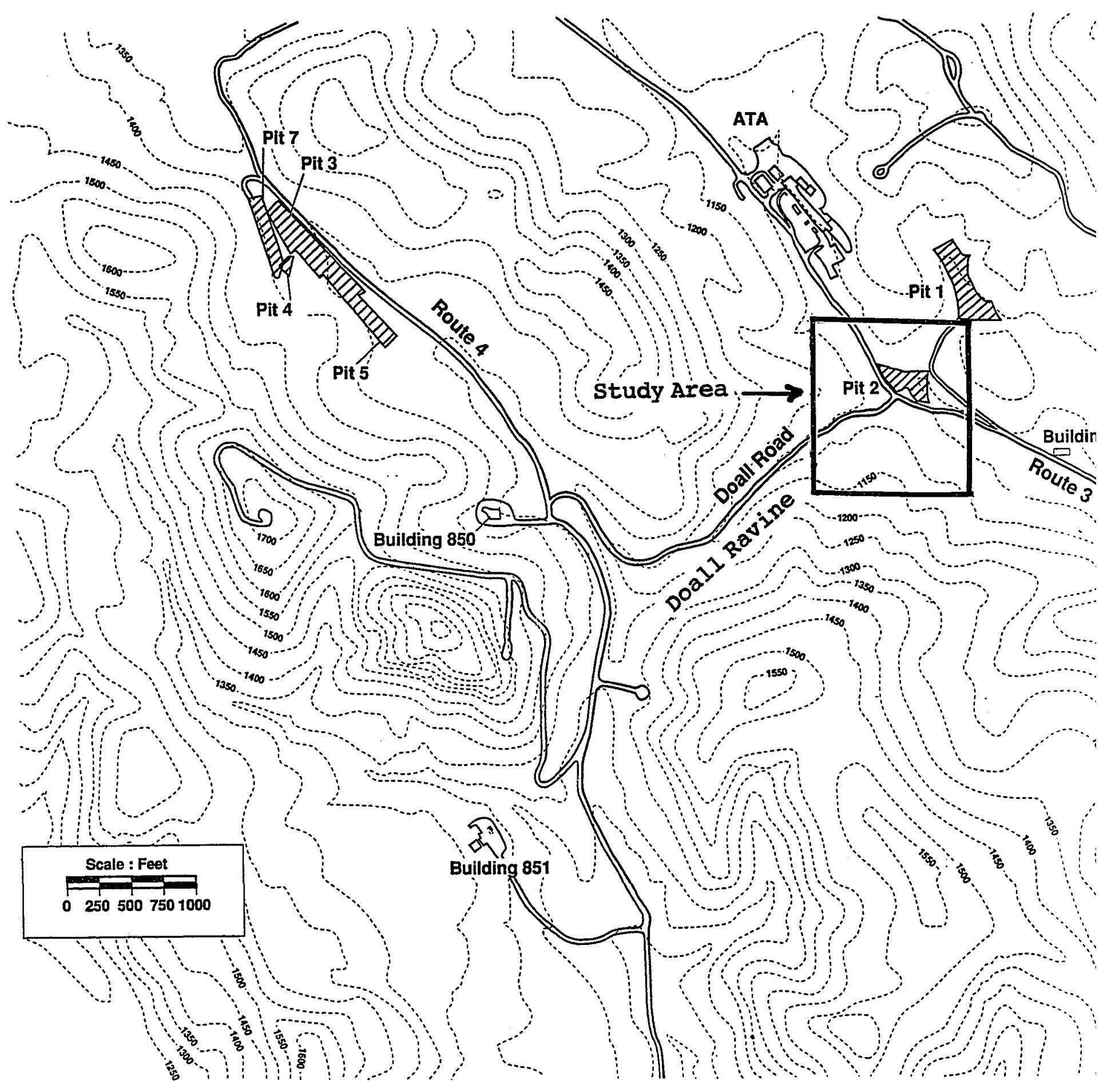

Figure 3. Topography, roads, landfills, and buildings of north-central site 300 . 

$-$ 
feet high and reaching elevations of 1,300 to 1,500 feet above mean sea level (MSL) bound Doall Ravine, which trends northeast and terminates at Elk Ravine about 3,000 feet from where it begins near Building 850. Landfill Pit 2 is immediately east of this juncture. Elk Ravine is a wide southeast trending valley which slopes up to a maximum of 1,550 feet in elevation with a valley floor elevation of approximately 1,050 feet MSL within the study area.

Regional Geology

Site 300 is located in the southern Altamont Hills within the Coast Range Physiographic Province. The Tertiary rocks that underlie site 300 are flanked on the south by Franciscan Assemblage rocks of the Diablo Range, on the east and west by Quaternary sediments of the San Joaquin and Livermore Valleys, and on the north by Upper Cretaceous Great Valley Sequence sediments (Figure 4).

The regional structural setting surrounding site 300 is dominated by major dextral strike-slip faults including the San Andreas, Hayward, Calaveras, and Greenville faults zones. In addition to these historically active regional faults, investigators have mapped nine other named faults in the region surrounding site 300 (Figure 5). 


\section{PLEASE NOTE}

Page(s) not included with original material and unavailable from author or university. Filmed as received.

8

FIGURE 4

University Microfilms International 


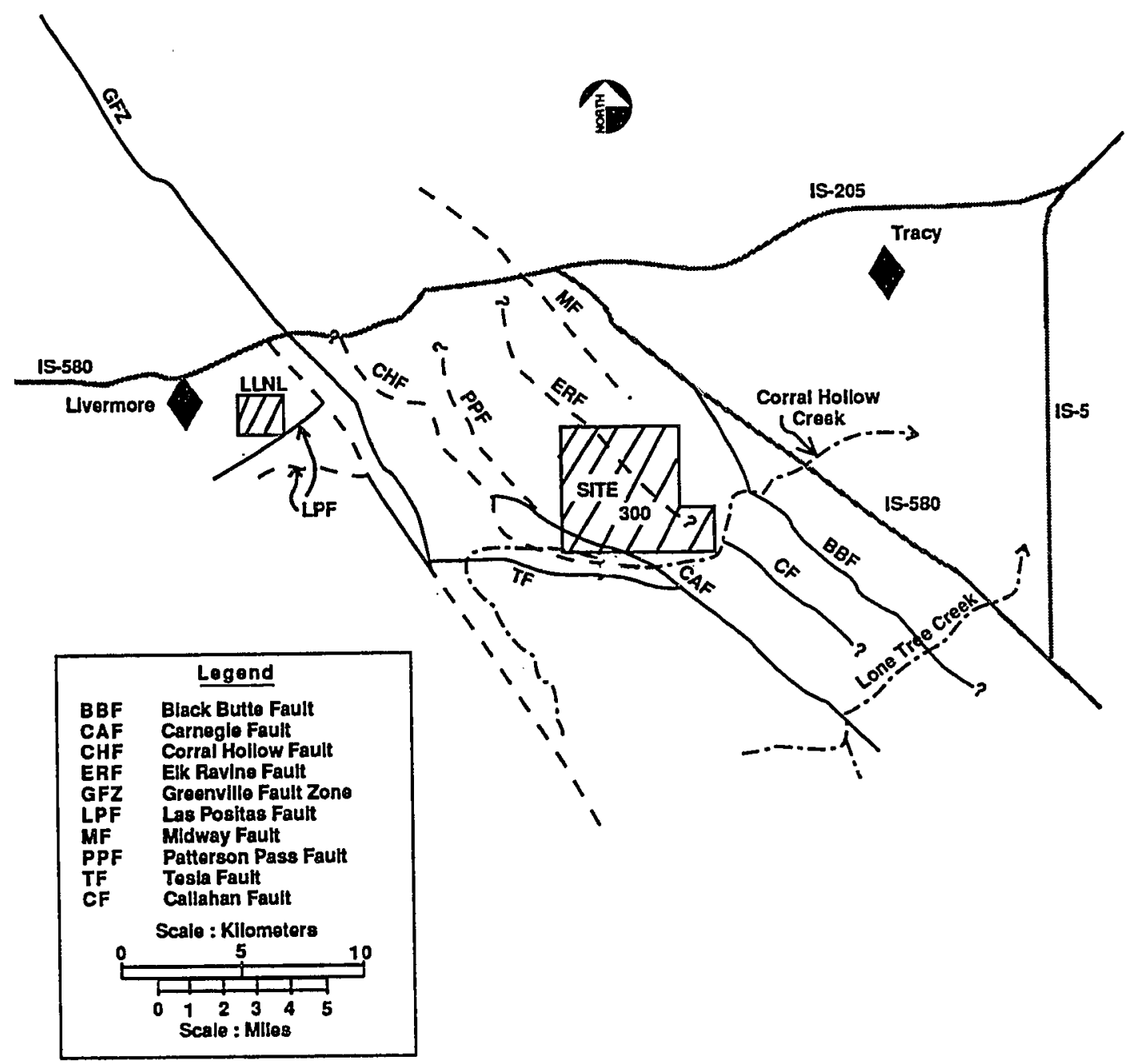

Figure 5. Map showing the principal faults in the area surrounding Site 300 (modified from Raymond, 1969; California Division of Mines and Geology, 1977; and Dibblee, 1980). 
Northern Site 300 Geology

The only bedrock unit exposed within the study area is the Neroly Formation (Figure 6). Within the study area, the Nerloy formation is composed of blue-weathering sandstones and siltstones, coarse conglomerates consisting of primarily of well rounded, vesicular, andesitic pebbles and cobbles, and interbedded tuffaceous shales. A complete section of the Neroly Formation is exposed on the southwest slope of the southern Doall Ravine ridge. This section, corrected for dip and topography, is about 300 to 350 feet thick. The Neroly Formation was subdivided for this study as follows:

Tnsb $b_{1}$ Massive blue sandstone, 100 to 125 feet thick, with calcareous claystones and tuffs. Sandstones show horizontal bedding, large scale cross-bedding, slumps and convolutions. A conglomerate sub-unit $\left(\mathrm{Tngl} \mathrm{I}_{1}\right)$ with a highly variable thickness of 25 to 80 feet is mappable throughout the northeastern part of site 300 and west of Disposal Pit 2. The major water-bearing zones in the study area occur within sandstones and conglomerates of the Tnsio unit. 


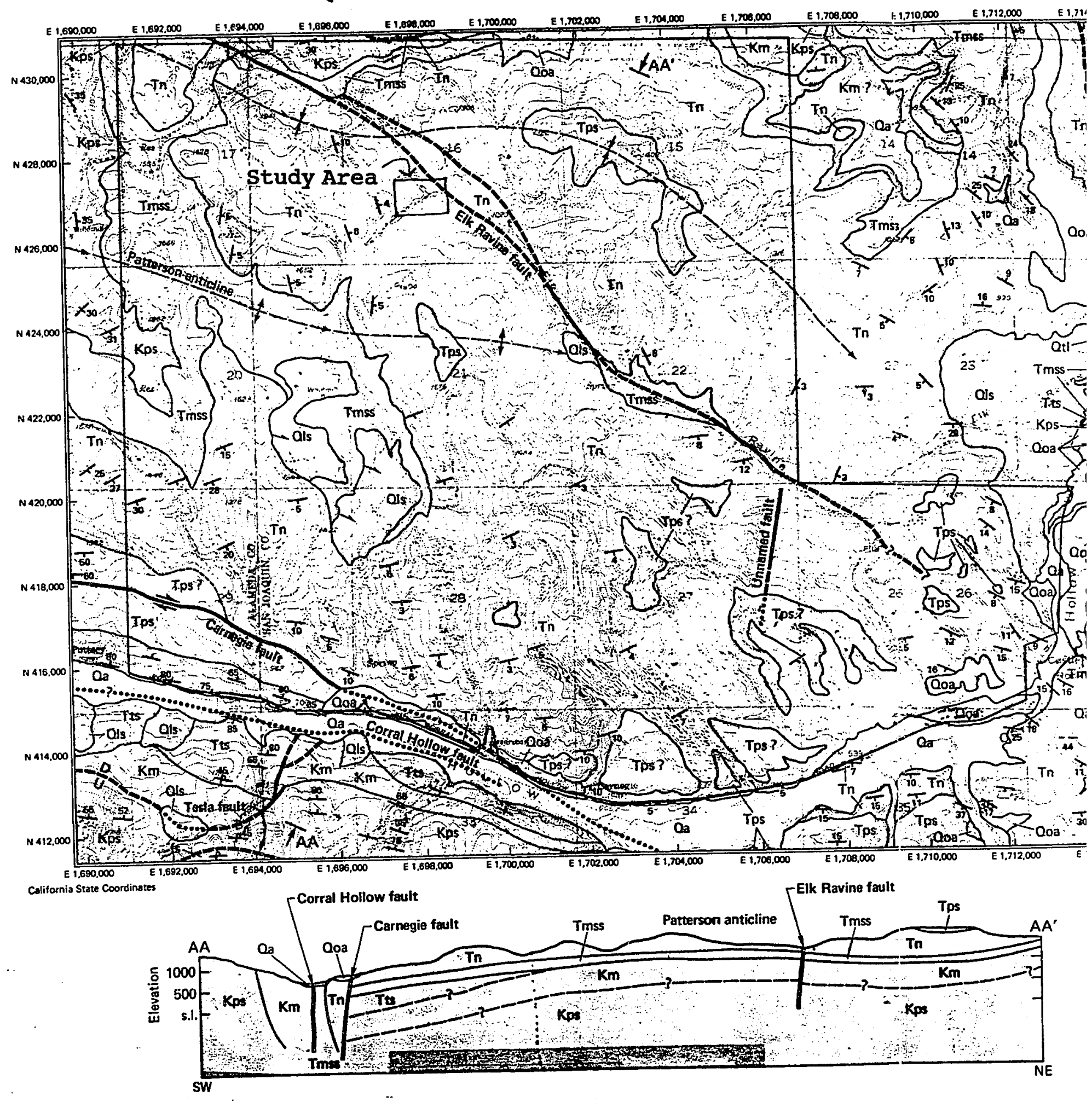

Figure 6. Map and cross section showing interpretations of geology of Site 300 prior to this investigation (Raber and Carpenter, 1983). 
$-$ 


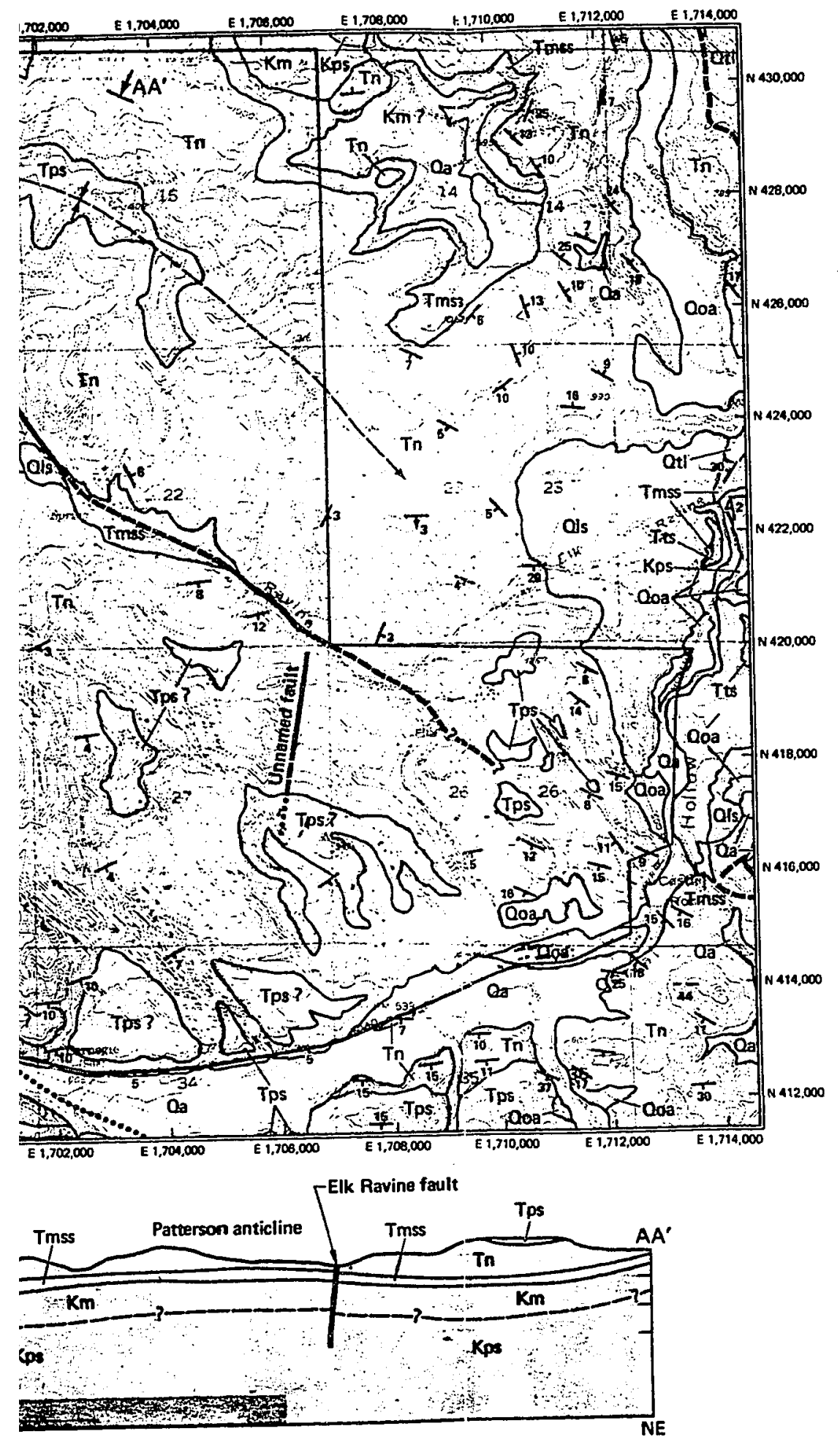

Legend

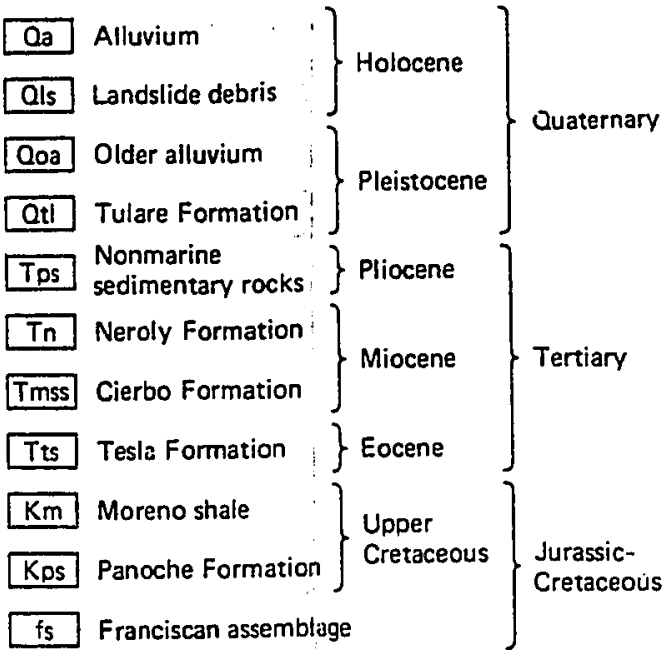

Contact

Dashed where gradatisnal or approximately located.

Fault

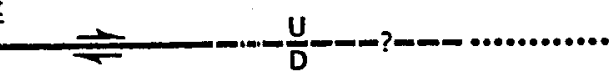

Dashed where inferreo; dotted where concealed; queried where existence doubtful; double arrows indicate strike-slip movement; $\mathrm{UI}$ - upthrown side, D - downthrown side, relatively

Axis of fold

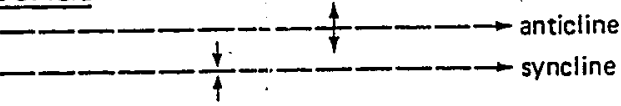

Arrow on axis indicates direction of plunge.

Strike and dip of strata

\begin{tabular}{|c|c|c|}
\hline$\underset{\text { inclined }}{\chi^{5}}$ & $\underset{\substack{\text { inclined } \\
\text { (approximate) }}}{\chi}$ & $\underset{\text { vertical }}{x}$ \\
\hline
\end{tabular}

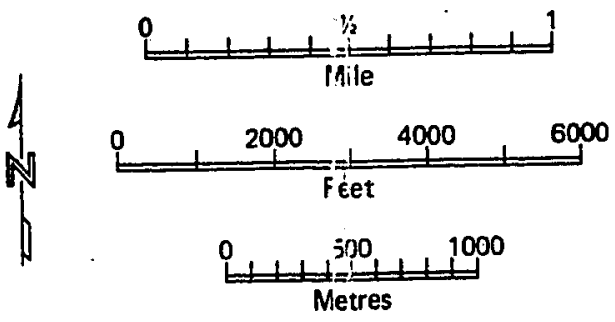

\section{interpretations} igation (Raber 
- 

Tnsc $_{1}$ : Sandstone, siltstone, and claystone, with some tuffs, 90 to 120 feet thick. The sandstone is more frequent toward the bottom.

Tnbs ${ }_{2}$ Upper blue sandstone, 50 to 60 feet thick, with thin interbeds of claystone, siltstone, and pebbles. Local, rare, lacustrine limestone interbeds, and rare mastodon, horse, bear-dog fossils near top.

Underlying the Neroly Formation is the cierbo Formation (Tmss). The cierbo Formation consists of friable, light gray to tan-weathering sandstones interbedded with gray claystones. In hand specimens, cierbo Formation sandstone is typically fine to medium-grained, biotite rich, with occasional rounded, black chert pebbles and granules. The contact between the cierbo and Neroly Formations in the Doall Ravine area is transitional. In the subsurface, typical cierbo claystone and sandstone lithologies alternate with Neroly lithology sandstone forming an approximately 50 foot transitional sequence below the Neroly conglomerate $\left(T n g l_{1}\right)$ exposed in eastern Doall Ravine. LINL personnel interprete the contact between the cierbo and Neroly Formations to be an erosional disconformity, including this 
transitional sequence as the top member of the cierbo Formation (Webster-Scholten, 1994).

Bedrock structure is dominated by the Patterson Anticline, which trends west-northwest/east-southeast as it crosses the central part of site 300 (Figure 6). South of the anticlinal axis, the bedrock sequence dips southwest toward Corral Hollow at an average of $10^{\circ}$. North of the anticlinal crest, beds dip toward the northeast an average of $10^{\circ}$.

No faults were mapped within the study area prior to 1980. The Elk Ravine Fault was initially mapped by Dibblee (1980) as an inferred fault with a northeast and a southwest branch in the vicinity of Disposal Pits 1 and 2 (Figure 6). The sense of movement associated with both branches of the Elk Ravine Fault was not labeled on Dibblee's published map of the area (Dibblee, 1980). The region between each branch of the fault was interpreted by LLNL personnel to be a down-dropped block (Raber and Carpenter, 1983). The west branch of the Elk Ravine Fault was also postulated by LLNL personnel (Raber and carpenter, 1983) to contain a component of dextral strike-slip motion. The actual fault surfaces of both branches of the fault are covered by slopewash material and alluvial deposits throughout most of the study area. 
Previous Hydrogeologic Interpretation

In previous investigations (Buddemeier, 1987; and Ruggieri et al., 1988), it was postulated that groundwater flow between the WFA and EFA follows the approximate axis of the Doall Ravine between Building 850 and Disposal Pit 2 . It was also postulated that the magnitude of the groundwater gradient becomes slightly steeper near the inferred location of the west branch of the Elk Ravine Fault as mapped by Dibblee (1980). East and west of the inferred fault the gradient was evaluated to be very gradual, particularly east of the fault.

The Building 850 tritium plume was interpreted to follow the regional groundwater gradient in the Doall Ravine area between Building 850 and Disposal Pit 2. In the vicinity of Disposal Pit 2, the plume (Figure 7) was postulated to depart from the interpreted groundwater flow direction and to flow along the inferred trace of the west branch of the Elk Ravine Fault as mapped by Dibblee. The physical properties of the inferred fault that caused the deflection of the tritium plume were not understood. 


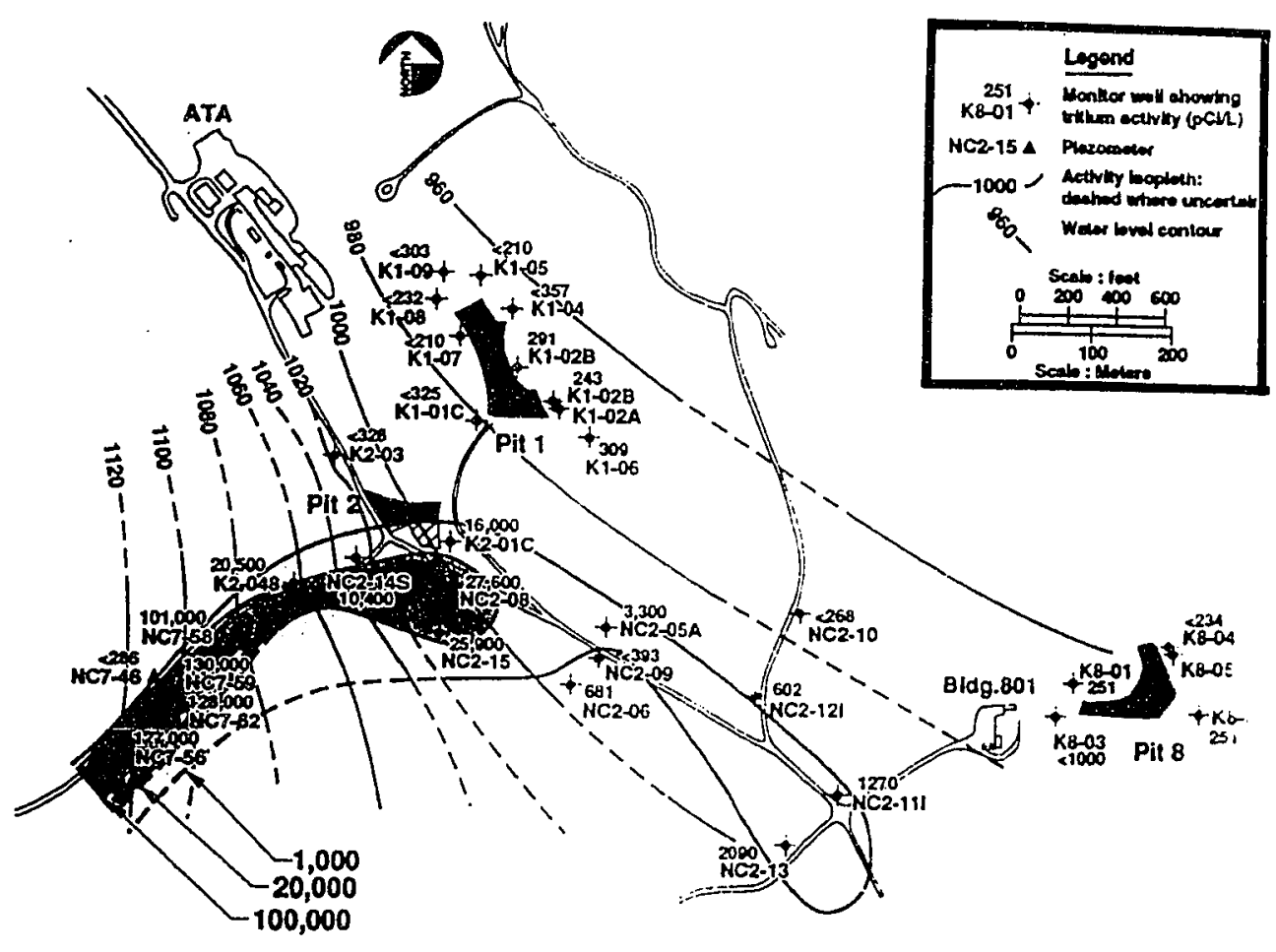

Figure 7. Schematic diagram showing interpretations prior to this investigation of East Firing Area groundwater contours and the Building 850 groundwater tritium plume near pit 2 . 
FIELD METHODS AND RESULTS

Geologic Mapping

Methods

Field mapping was used to locate and document the surface rock types and structural features within the eastern Doall Ravine - Pit 2 study area. The geology of the study area was mapped in the field for this investigation between July 1988 and March 1989. Field data were plotted on unpublished topographic base maps, scale 1-inch to 200 feet, produced from aerial photographs prepared for LLNL by the spink Corporation (Spink, 1977), and posted onto a 1inch to 600 feet scale base map. Aerial photographs were used as mapping aids. A Brunton compass was used to measure attitudes and to help locate contacts. A pocket altimeter was also used as an aid in plotting contacts.

\section{Surface outcrops}

Correlation of strata within major northwest striking fault blocks appears to be excellent, based upon outcrop data. These correlations for sequences greater than 20 feet thick can be carried northwest to southeast for two-or-more miles beyond the study area boundaries. Correlations 
running northeast to southwest, or perpendicular to the fault bounded blocks, are more difficult due to possible translational movements along documented faults. A geologic map of the eastern Doall Ravine - Pit 2 study area is presented as Figure 8 .

Neroly Formation The only formation present at the surface in the study area is the Neroly Formation. The Neroly Formation has been subdivided into as many as eight informal lithologic members in the northern part of site 300 (Raber and Carpenter, 1983; Carpenter et al. 1988; and Taffet et al., 1990). Rocks in the Building 850/Doall Ravine area are directly correlative to at least three of these eight informal lithologic members.

The Neroly upper blue sandstone $\left(\mathrm{Tnsb}_{2}\right)$ unit is exposed near Building 850 and on the hilltops in western Doall Ravine. No water-bearing zones have been found to be present in this unit near the study area. The Neroly upper blue sandstone $\left(\mathrm{Tnsb}_{2}\right)$ is composed of massive to moderatelybedded, fine- to medium-grained, blue-gray silty sandstones. Near Building and 850 and western Doall Ravine, this unit varies in thickness from 30 to 60 feet.

Conformably underlying the upper blue sandstone is the middle siltstone and claystone unit $\left(\mathrm{TnSC}_{1}\right)$. These rocks commonly contain sandstone interbeds, but the Tnsc informal member is distinguished from the overlying blue 


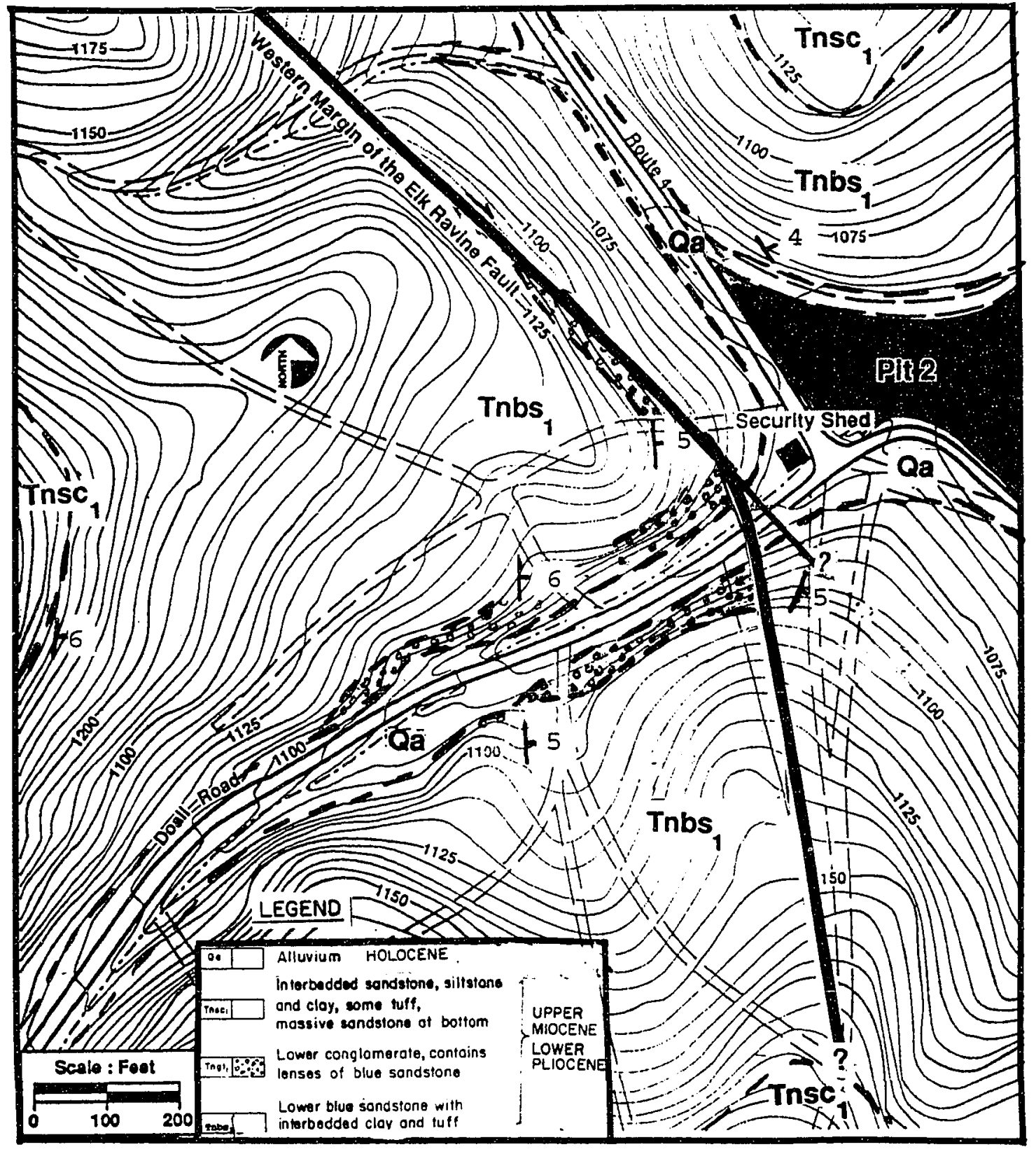

Figure 8. Geologic Map of the eastern Doall Ravine and Pit 2 study area. 
sandstone by a marked increase in interbeds of silty claystones, mudstones, and silty sandstones. In the field, this unit generally appears as a more resistant cliff forming unit as compared to the overlying upper blue sandstone, and the underlying lower blue sandstone units. Within the study area, the thickness of the middle claystone varies from 90 to 120 feet. No water-bearing zones have been found to exist in the middle claystone within the Doall Ravine area.

The Neroly lower blue sandstone $\left(\mathrm{Tnbs}_{1}\right)$ unit is the most extensive unit in the study area and contains significant bedrock water-bearing zones. The unit is well exposed in eastern Doall Ravine and near the Advanced Test Accelerator (ATA) to the north. Strata of this unit consist dominantly of blue-gray sandstones with interbedded sandy siltstones, mudstones, and claystones. An areally extensive conglomerate unit $\left(\operatorname{Tng} l_{1}\right)$, is a submember of unit $\operatorname{Tnbs}_{1}$ and is located near the base of Tnbs $_{1}$. In outcrop and in drill core (Toney and Crow, 1988), approximately 30 feet of additional blue sandstone underlie sub-unit Tngl, forming the lowest identifiable segment of $\mathrm{Tnbs}_{1}$ and the Neroly Formation.

Underlying this segment in the stratigraphic section is a 120 to 200 feet thick sequence of interbedded cierbo Formation (Tmss) and Tnbs 1 lithology rocks. The previously 
recognized informal Neroly basal claystone unit (Tnsc of Taffet et al., 1989a) does not appear within the study area based on a review of the drill core data.

Alluvium and Colluvium The base of Doall Ravine contains unconsolidated deposits of interbedded sand, silt, clay, and occasional gravel lenses. Thickness of these alluvial units ranges from a few to up to at least 39 feet). Colluvial materials that overlie the bedrock sequence consist chiefly of dark-brown silty clay and silt grading to clayey and silty sand with some gravel. Colluvial layers vary in thickness from a few inches to several feet. Caliche horizons often form at the bases of these deposits.

\section{Structure}

Three structural features have been identified within the eastern Doall Ravine - Pit 2 study area and surrounding areas from surface geologic mapping and field observations. These features are: The northwest-southeast striking Elk Ravine Fault, the east-west striking Patterson Anticline, and a newly identified northeast striking syncline (EFA Syncline). A schematic map of mapped faults and folds within northern site 300 is included in Figure 9.

Folds The western portion of the mapped area is dominated by the broad, open, nearly symmetrical Patterson 

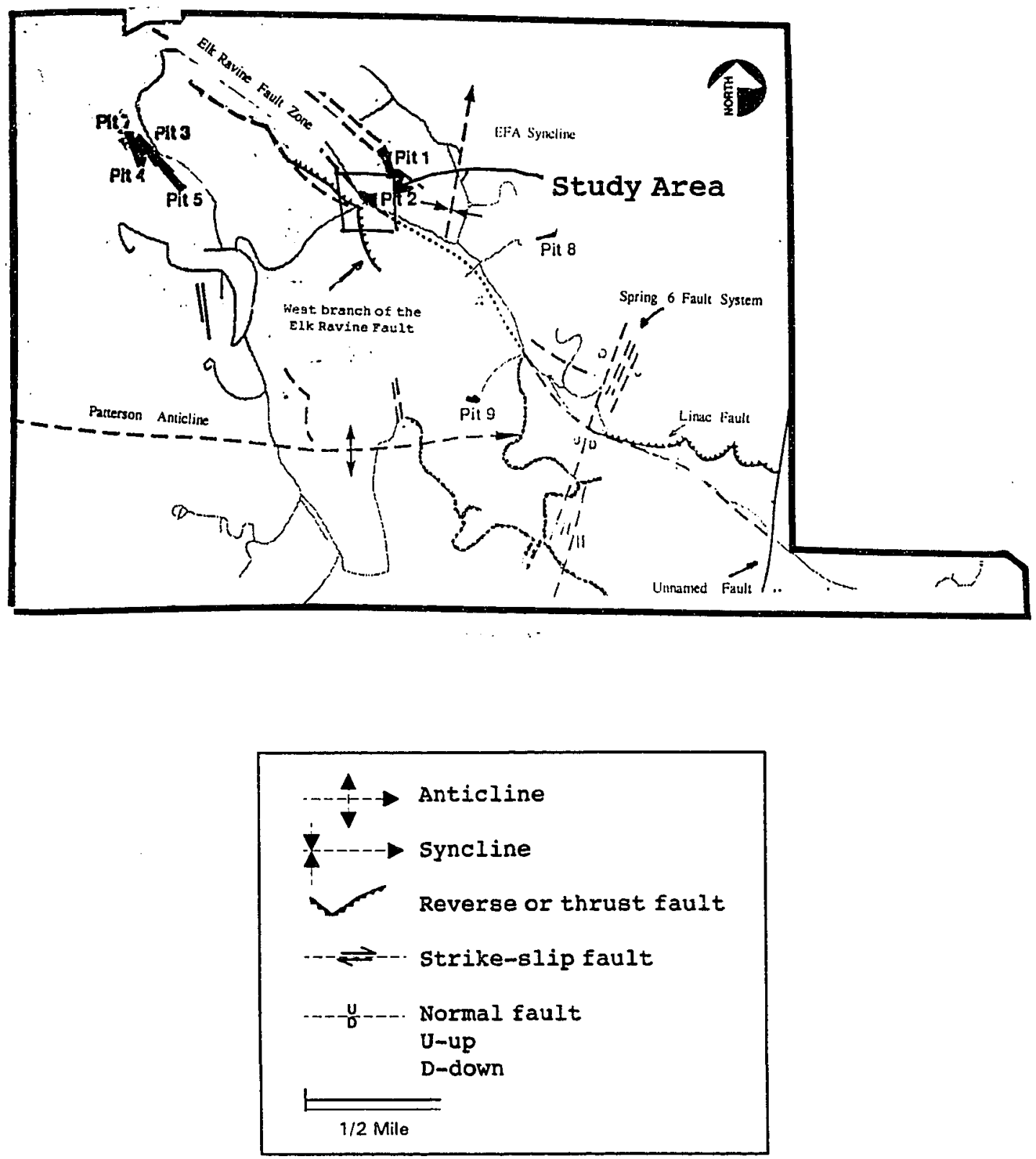

Figure 9. Schematic map of mapped faults and folds within northern Site 300 (Dugan and Mateik, 1990). 
Anticline. Originally mapped by Huey (1948), this broad structure trends roughly east-west and plunges gently to the east (Figure 6). Beds of the Neroly Formation are exposed on both limbs of the fold. The study area lies within the northern limb of the Patterson Anticline. Within Doall Ravine, the bedrock dips an average of 5 to 10 degrees to the northeast. A broad three mile wide, asymmetrical, north-northeastward plunging syncline, with gently dipping limbs, was discovered and mapped within the EFA during this study (Figure 9). The axis of the EFA syncline is estimated to be approximately 1,000 to 1,500 feet east of Pit 2 and appears to be plunging 5 to $7^{\circ}$ to the north-northeast. The western end of the EFA Syncline appears to have been truncated by the western margin of the Elk Ravine Fault. Cretaceous rocks of the Panoche Formation are exposed near the northern boundary of site 300 where they rise on the northern limb of the EFA syncline. Panoche and cierbo Formation rocks are exposed east of the western margin of the Elk Ravine Fault reflecting movement along the fault. Neroly Formation $\left(\mathrm{Tnbs}_{1}\right.$ ) rocks are exposed west of the fault margin. Within the boundaries of site 300 , the rest of the northern limb and most of the southern limb of the East Firing Area syncline contain Neroly Formation rocks. The southern flank of the EFA syncline steepens south of the Spring 6 Fault system (Figure 9). 
Faults The Elk Ravine Fault is approximately eight miles in length (Figure 4). The northern limit of the fault is located approximately 5 miles north of site 300 . The southern limit of the fault is located near the east-central boundary of site 300 (Figure 9). Within the area impacted by the Building $850 /$ EFA groundwater tritium plume, the fault consists of a west and east branch.

A surface splay of the west branch of the Elk Ravine fault was identified during field mapping activities performed for this study. Approximately 200 feet west of Pit 2 on the northern side of Doall Ravine, a blue sandstone $\left(\mathrm{Tnbs}_{1} \text { ) is faulted against a conglomerate (Tngl }\right)_{1}$ ) (Figure 8). A single fracture separates the aforementioned rock units, with multiple lesser fractures located within the blue sandstone unit east of the main fracture. The east branch of the Elk Ravine Fault was not examined during field operations performed for this study. It was encountered in a trench (TR-EFA-01) excavated by LINL personnel approximately 100 feet north of Pit 1 (Hoffman, 1988). Westward dipping fault splays were observed within the exploratory trench. 
Exploratory Trenches

To facilitate the mapping effort in the eastern Doall Ravine - Pit 2 area, four trenches were excavated to remove colluvial materials covering key bedrock exposures in the vicinity of the west branch of the Elk Ravine Fault. These trenches were excavated, logged, and photographed for this investigation (Figure 10). Exploratory Trench TR-EFA-02 was excavated to enable evaluation of fractures associated with the west branch of the Elk Ravine Fault along the northern slope of Doall Ravine where the fault was initially observed for this study. The fault was measured and evaluated to be striking approximately $\mathrm{N} 60^{\circ} \mathrm{W}$, with a dip of $63^{\circ}$ to the north (Figure 11). The surface expression of the west branch of the Elk Ravine fault was measured to be approximately 75 feet wide and consisted of a collection of narrow (1/8 to 1/2-inch wide) calcite-healed fractures. Logs of exploratory trenches excavated for this study are presented in the Appendix.

Three additional exploratory trenches, TR-EFA-03 through TR-EFA-05, were excavated approximately 100 to 250 feet south of Trench TR-EFA-02 to enable evaluation of the west branch of the Elk Ravine Fault south of Doall Ravine. Small scale eastward dipping displacement zones (shear zones) approximately 1/2-inches to one foot in width Figure 


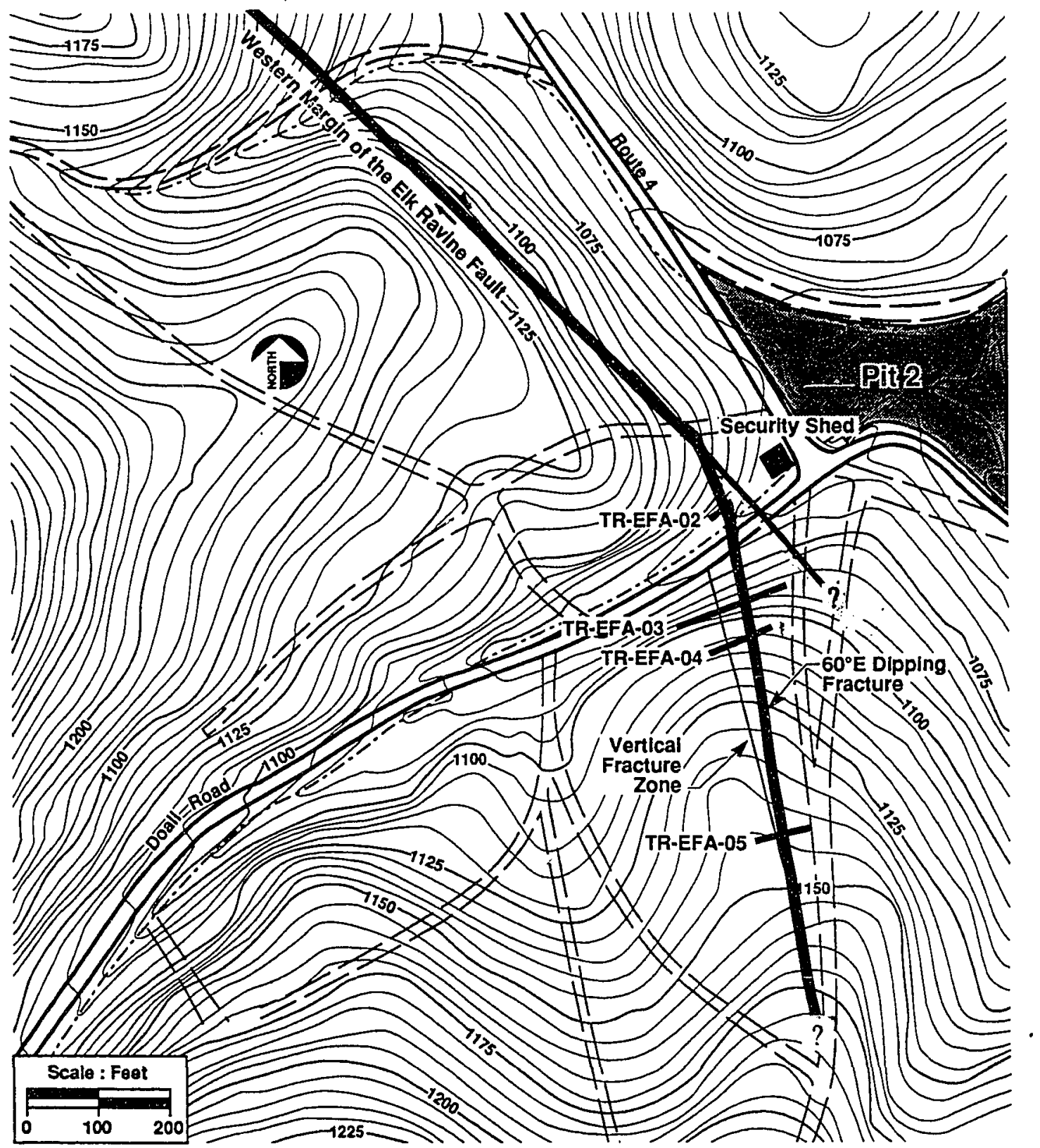

Figure 10. Locations of exploratory trenches in the eastern Doal1 Ravine - Pit 2 area. 


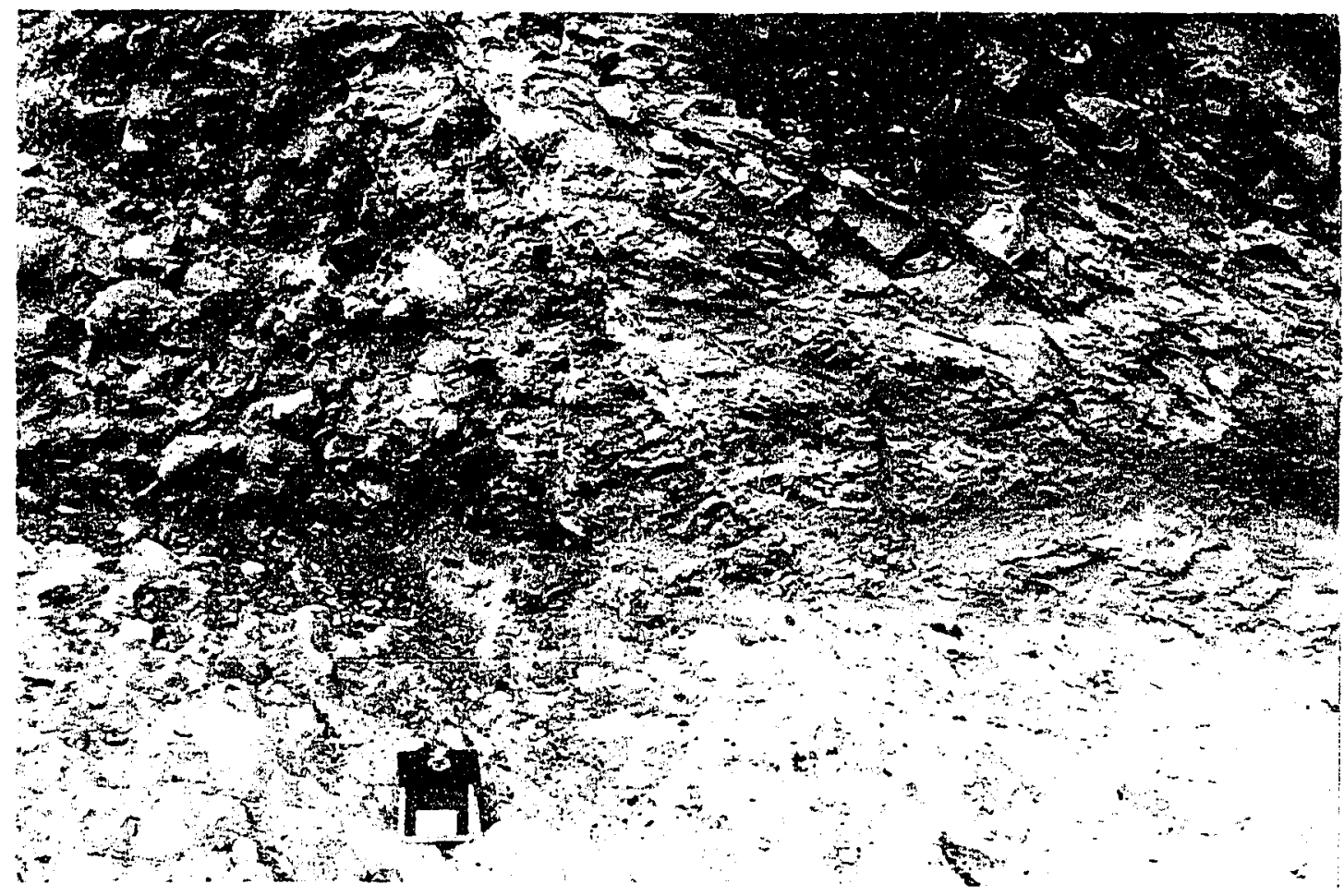

Figure 11. Photograph of Neroly blue sandstone (Tnbs ${ }_{1}$ ) faulted against Neroly conclomerate ( $\left.T n g l_{1}\right)$ within trench TR-EFA-02. Note the two-inch wide I.D. badge located on the trench floor for scale. 
12) were encountered in each of the three trenches. The southern limit of the splay of the west branch of the Elk Ravine Fault is unknown south of trench TR-EFA-05. 


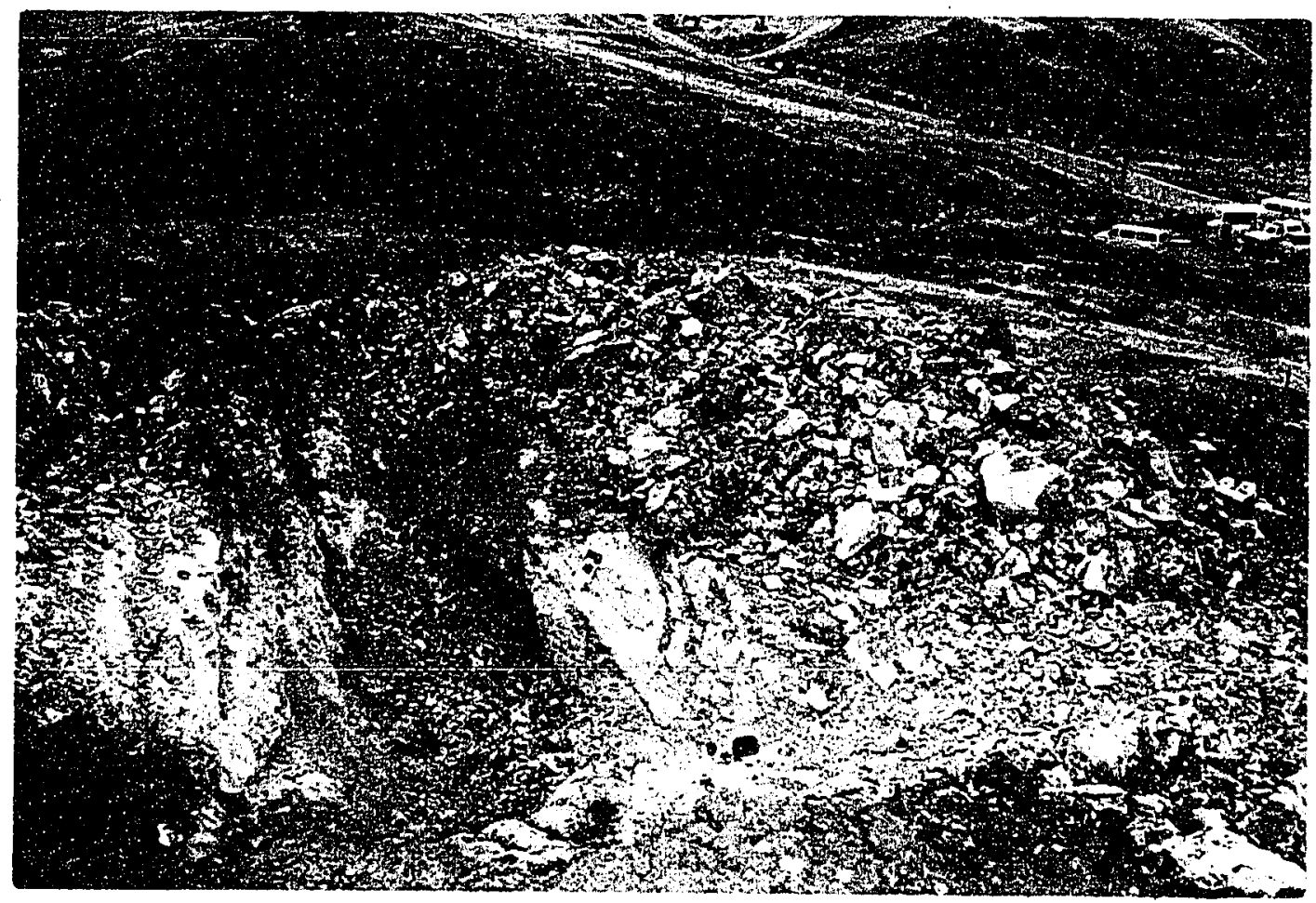

Figure 12. Photograph of trench TR-EFA-05 in the foreground and trench TR-EFA-02 in the background. Note compass and I.D. badge in foreground, and vehicles for scale. The I.D. badge is placed just right of the exposed, high angle, orange-stained shear zone. 
HYDROGEOLOGIC EVALUATION

To evaluate the hydrogeology near the intersection of the Doall and Elk Ravines, exploratory boring and monitoring well logs were reviewed, including available moisture logs, geophysical logs, lithologic logs, and fracture logs (Taffet et al., 1990). Depth to water levels and tritium activity tables (Taffet et al., 1990) were also reviewed, plotted on well location maps, and contoured.

Hydrogeologic Cross Section

Hydrogeologic cross section $A-A^{\prime}$ was prepared to portray the subsurface distribution of lithologies and water-bearing zones at depth along Doall Ravine and a segment of Elk Ravine near Pit 2 (Figure 13). The cross section follows a transect trending approximately parallel to dip along the axis of Doall Ravine. The newly identified splay of the Elk Ravine fault is depicted near the eastern end of the cross section. The fault location is based on the trench $\log$ information presented in the previous chapter.

As depicted in Figure 13, the geologic materials encountered in boreholes drilled within the area of cross section $A-A^{\prime}$ can be classified into three general 


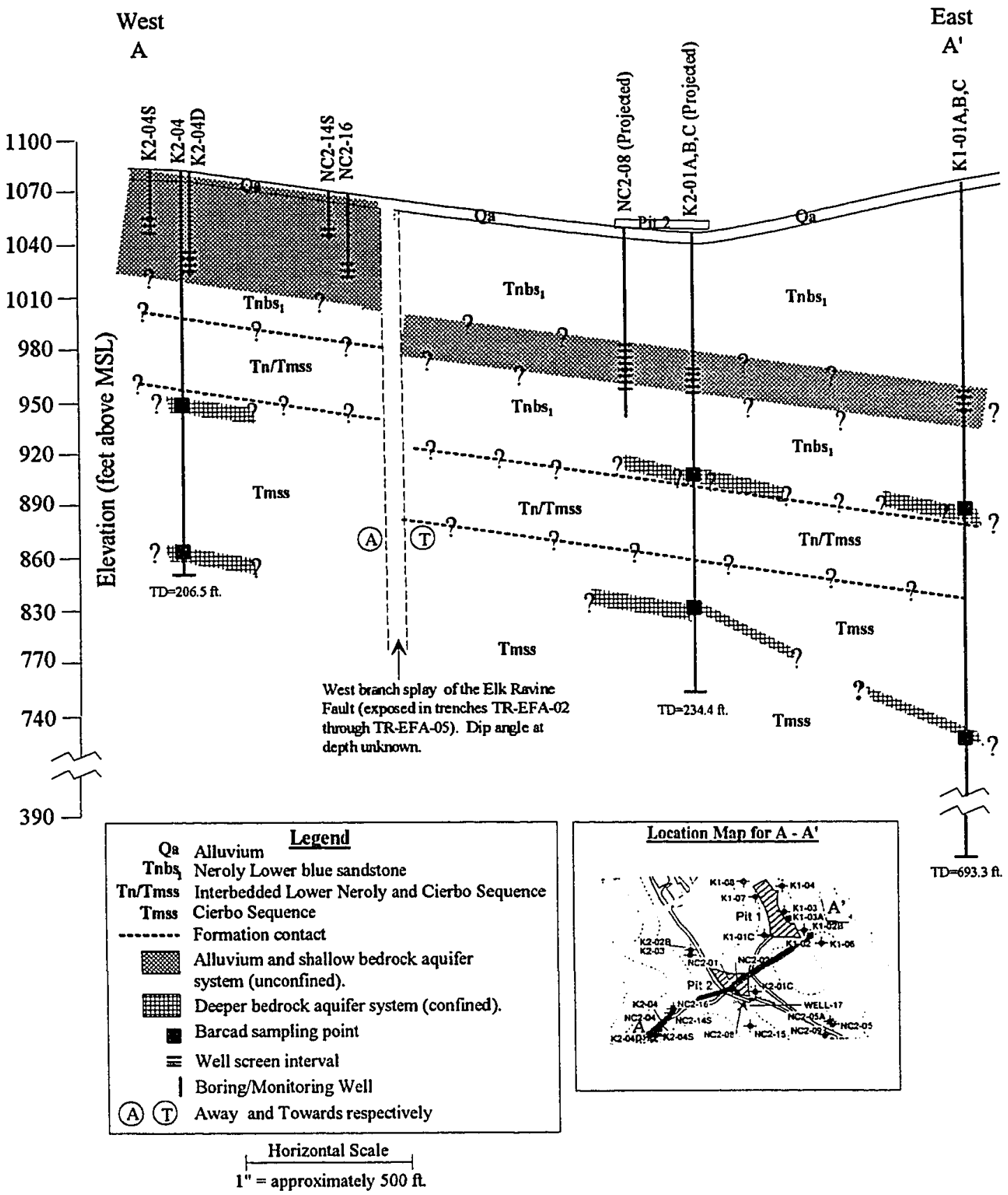

Figure 13. Schematic hydrogeologic cross section $A-A^{\prime}$ illustrating the alluvium and shallow bedrock aquifer system and the deeper bedrock aquifer system. 
categories: 1) shallow unconsolidated alluvial materials encountered along the axis of the Doall Ravine Stream channel, 2) underlying shallow, moderately weathered and fractured bedrock of the Neroly Formation unit Tnbs, (including sub-unit $\operatorname{Tng} 1_{1}$ ), and 3) deeper bedrock sequences of lower Neroly (Tnbs, ) and upper Cierbo Formation sandstones and siltstones. East of the splay of the Elk Ravine fault, it appears that the depth to the base of Tnbs, is deeper than west of the fault. It is not clear if this interpreted offset is the result of a component of normal fault displacement or primarily results from strike-slip movement along the fault.

Identification of Water-occurrence zones

Groundwater occurs in two principal aquifer systems beneath Doall Ravine and Elk Ravine near Pit 2. The shallowest zone consists of seasonally saturated ravine stream channel sediments hydraulically connected with underlying saturated fractured bedrock. The water-bearing alluvium is limited in extent to a narrow 50 to 60 foot wide band parallel to the axis of the Doall Ravine. This system extends to a total depth of approximately 60 below ground level. The second aquifer system is confined, and consists of saturated fractured bedrock encountered at varying depths 
between 100 to 200 feet below ground level. Elevated tritium activity levels exist only in groundwater sampled from the shallow aquifer system. The aquitard separating the shallow bedrock groundwater system from the deeper system is a relatively unfractured claystone subunit within the transitional Neroly and Cierbo Formations contact interval.

In Doall Ravine 300 feet west of well $\mathrm{k} 2-04$ the alluvial ravine sediments come in contact with the permeable blue sandstone $\left(\mathrm{Tnbs}_{1}\right)$ of the Neroly Formation. At this location, seepage occurs from the alluvium into the first encountered water-occurrence zone of the shallow bedrock groundwater system as illustrated in cross section $A-A^{\prime}$. High tritium groundwater which discharges from bedrock into the alluvium near the head of Doall Ravine is, at least partially, returned to bedrock at this point. To the west tritium is prevented from seeping into the bedrock by the low permeability of the claystone unit. East of the west branch of the Elk Ravine fault, the shallow water-occurrence aquifer occurs at greater depths and as a number of interconnected, thin, confined water-bearing zones (Taffet et al., 1990).

In former monitoring well k2-04, approximately 800 feet west of Pit 2, within Doall Ravine, two deeper wateroccurrence zones within the deeper bedrock aquifer system 
were monitored by Barcad sampling devices and pressure transducers. Barcads are capable of propelling water samples to the surface for laboratory analyses. The upper Barcad was positioned in a water-occurrence zone approximately 110 feet below ground level within the transitional Tnbs $/$ Tmss interval. The deeper Barcad was positioned in a water-occurrence zone approximately 190 feet below ground level within Cierbo Formation (Tmss). The deeper water zones monitored within well K2-04 by the pressure transducers are confined zones.

In the eastern portion of Doall Ravine, one bedrock water-occurrence zone within the shallow bedrock aquifer system and two bedrock water-occurrence zones within the deeper bedrock aquifer system are interpreted west and east of the western branch of the Elk Ravine fault as illustrated on geologic cross section $A-A^{\prime}$ (Figure 13). The wateroccurrence zones within the deeper bedrock aquifer system are confined. Water-occurrence zones within the shallow bedrock aquifer system are interpreted to be unconfined, crossing the fault with approximately a 30 feet elevation head loss resulting from cemented fault gouge, or the infilling of fractures by precipitates. 
Hydraulic Gradient

Water levels in wells throughout the EFA are measured monthly to the nearest 0.01 foot and contoured on a quarterly basis by LLNL personnel. An interpreted groundwater gradient map of the EFA for the second quarter 1991 is presented on Figure 14. The hydraulic gradient in the area between Building 850 and mid Doall Ravine appears to be towards the east $\left(\mathrm{N} 80^{\circ} \mathrm{E}\right.$ to $\left.\mathrm{N} 110^{\circ} \mathrm{E}\right)$ with a magnitude of 0.005. This is consistent with the dip of the strata in this area.

An extremely steep hydraulic gradient was interpreted at the east end of Doall Ravine indicating the presence of a groundwater flow barrier. This coincides with the location of the west branch of the Elk Ravine fault. The barrier is a low permeable zone that allows migration of groundwater and tritium, but with a very steep hydraulic gradient. North of Doall Ravine, few data points exist to enable a definitive interpretation of the groundwater gradient near the west branch of the Elk Ravine Fault.

East of the west branch of the Elk Ravine fault the magnitude of the hydraulic gradient is much less (0.01) than immediately to the west. The flow direction is variable, being more northeasterly near pit 1 and more southeasterly near Pit 8. A hydraulic barrier similar to the barrier 


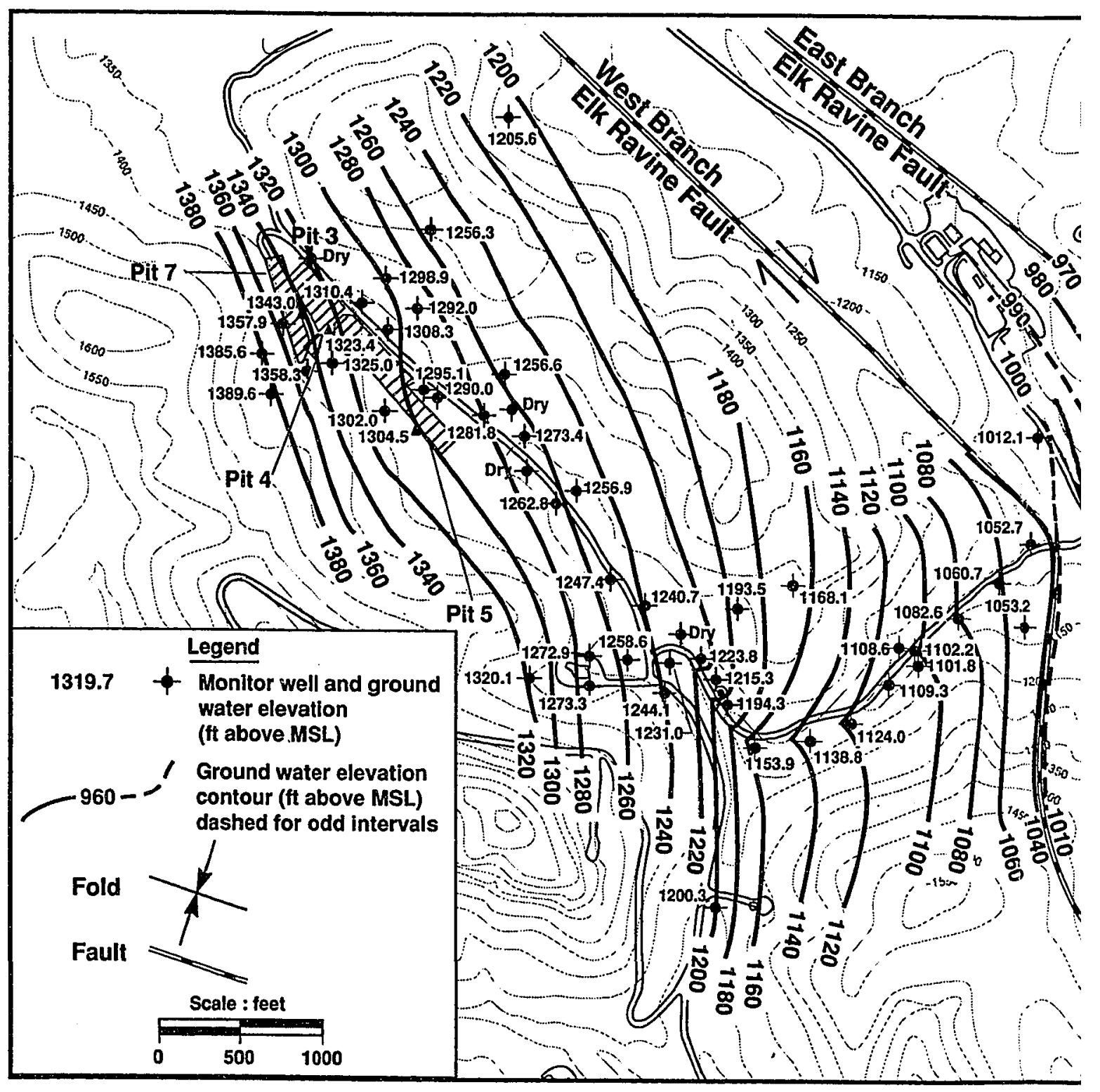

Figure 14. Groundwater elevation contour map of the alluvium and shallow bedrock aquifer system within the East and West Firing Area, May 1991. 


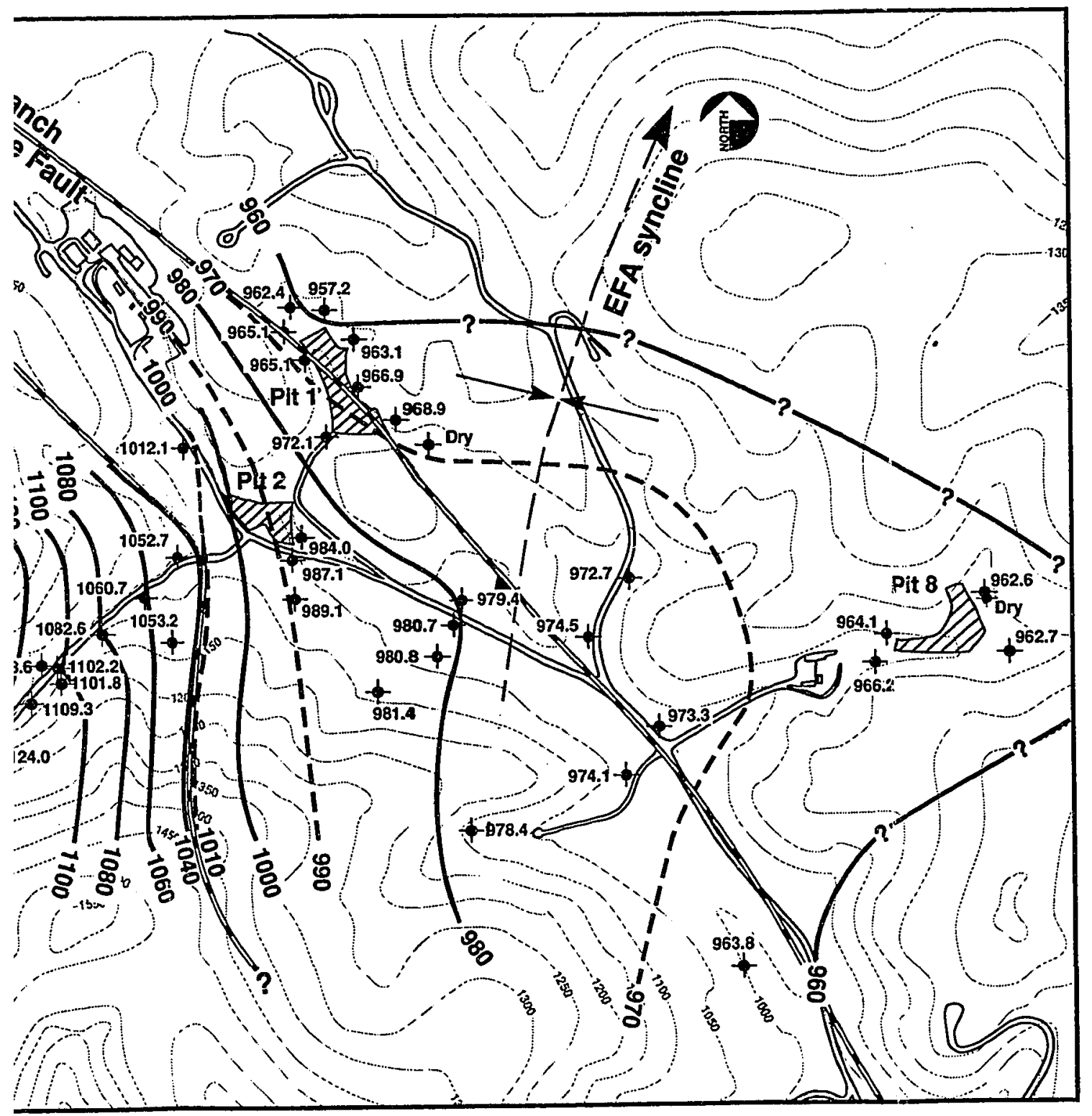


caused by the west branch of the Elk Ravine Fault does not appear to be caused by the east branch of the fault.

Well Yields

Monitoring wells throughout the study area screened within the shallow bedrock aquifer system or within the deeper bedrock aquifer system, yield between 1 to 2 gallons per minute west of the west branch of the Elk Ravine fault, and 10 to 20 gallons per minute east of the fault. This may be attributable to the thicker permeable units (primarily sandstones) present east of the fault. This difference supports significant lateral offset along the fault. These more transmissive units are also reflected in a gentler hydraulic gradient.

\section{Distribution of Tritium in Groundwater}

Selected wells throughout the EFA are sampled and analyzed for tritium activity on a quarterly basis by LLNL personnel. A map showing interpreted contours of the distribution of the Building 850 groundwater tritium plume within the WFA and EFA is presented in Figure 16. Two migration pathways most likely account for the distribution of tritium in groundwater between western Doall 


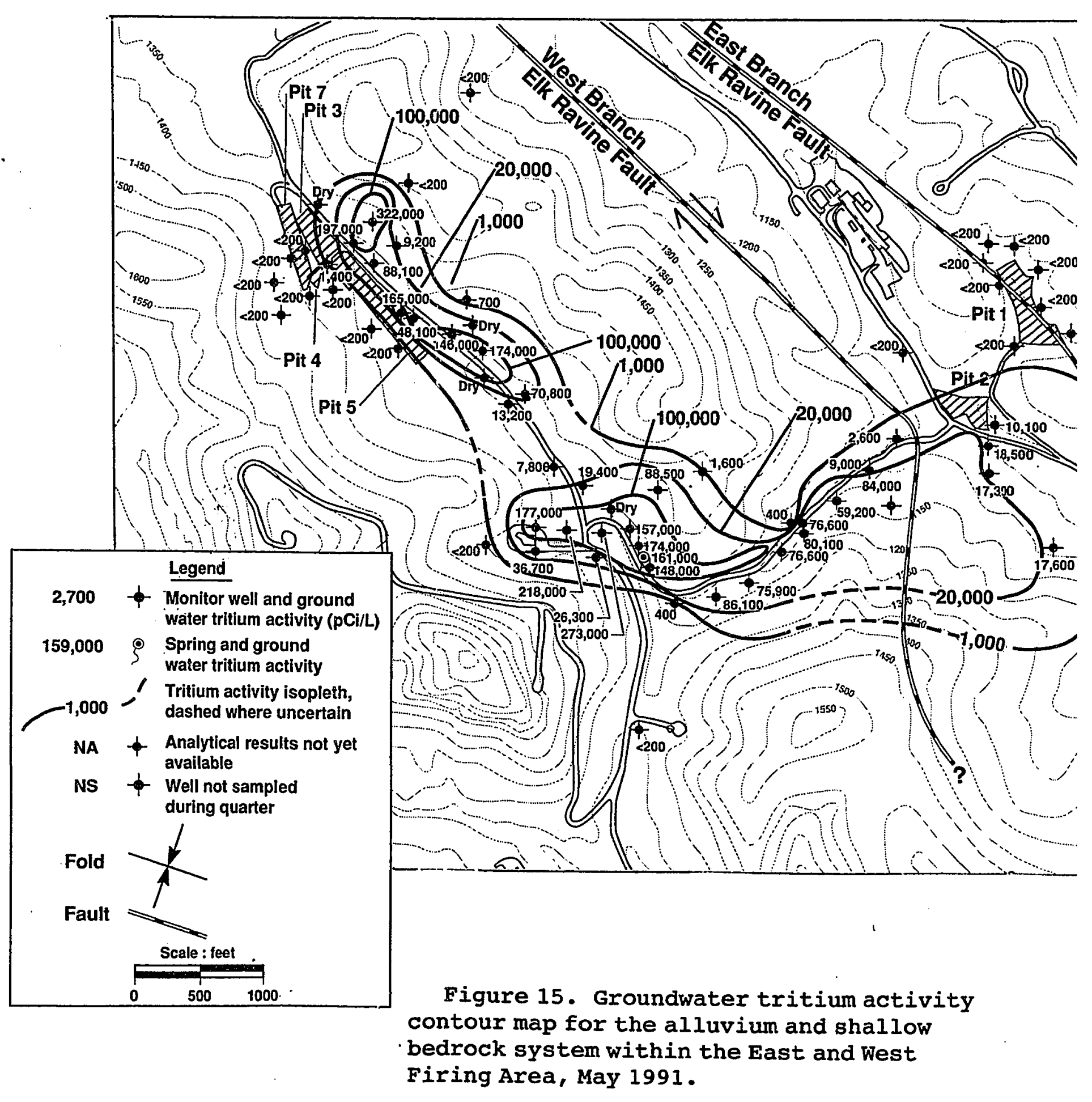





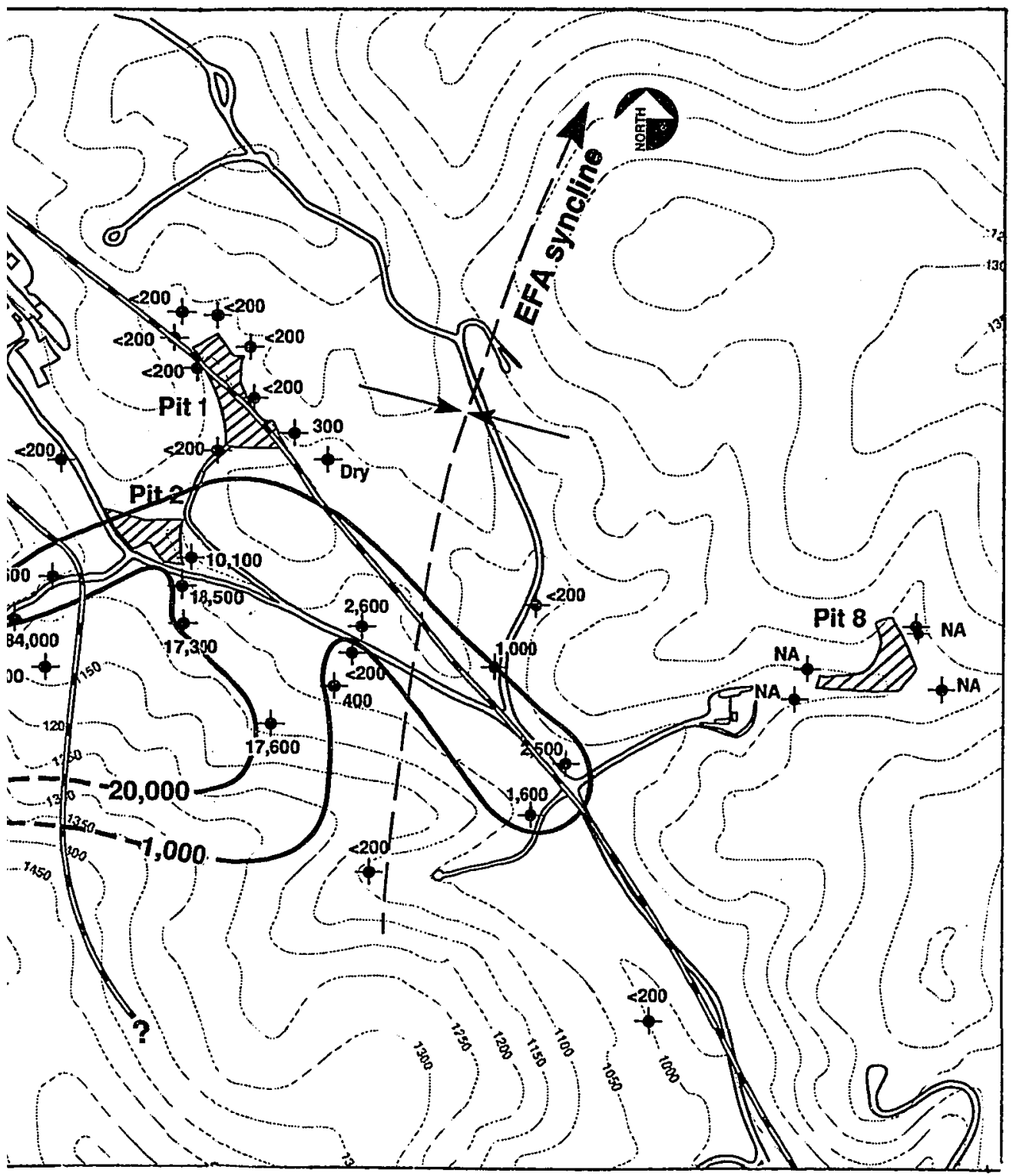

activity

allow

West 


\begin{abstract}
Ravine and Elk Ravine: 1) flow through saturated, permeable, alluvium and weathered bedrock along the length of Doall Ravine, and 2) flow through saturated bedrock in accordance with the regional southeastward hydraulic gradient. The migration of the tritium plume through the saturated bedrock pathway does not appear to have reached Elk Ravine from western Doall Ravine. The low but elevated levels of tritium present along the axis of Elk Ravine represent migration through the permeable alluvium with some infiltration through fractures into underlying rock.
\end{abstract}




\section{CONCLUSIONS}

Two newly identified structural features have been mapped within the immediate area of eastern Doall Ravine and Pit 2: the EFA syncline and a branch of the Elk Ravine Fault as exposed in exploratory trenches TR-EFA-02 through TR-EFA-05.

The predominant sense of movement on the newly mapped and trenched segment of the west branch of the Elk Ravine Fault has probably been right lateral strike-slip motion. This conclusion is suggested by several independent lines of evidence. First, different lithologies generally exist across the fault. East of the fault primarily sandstones are present, whereas west of the fault abundant conglomerate deposits exist in outcrop and in the subsurface. Second, the East Firing Area syncline is located east of the fault, whereas beds of the Patterson Anticline exist west of the fault. The two structures appear to intersect at nearly $90^{\circ}$. Third, different hydraulic gradients exist east and west of the fault. Fourth, different well yields exist on either side of the fault.

Based on cross section $A-A^{\prime}$, groundwater flow and tritium migration within the Doall Ravine and Pit 2 area occurs within two aquifer systems: a shallow, unconfined, aquifer system and a deeper, confined, aquifer system. The westerly splay branch of the Elk Ravine Fault zone 
identified in eastern Doall Ravine forms a significant hydraulic barrier to groundwater flow and tritium migration within each aquifer system. The barrier is a low permeable zone that allows migration of groundwater and tritium, but with a very steep hydraulic gradient. A 30 foot head loss results as ground-water flows across the fault.

Early studies (Ruggieri et al., 1988) found a discrepancy between the tritium distribution and the groundwater flow direction as determined by the groundwater elevation map. After further investigation, it is concluded that the EFA tritium plume does not depart from the regional groundwater flow direction near Pit 2, and that the plume and ground-water are flowing in the same direction east of the west branch of the Elk Ravine Fault. Groundwater east of the fault is flowing in a northeastward to southeastward direction, not purely northeastward as previously postulated. Stratigraphy and dips, rather than the west branch of the Elk Ravine fault, appear to have the greatest influence on the direction of groundwater migration. 
REFERENCES CITED

Buddemeier, R. W, (1985), Investigation of Tritium in Groundwater at Site 300, Lawrence Livermore National Laboratory, Livermore, Calif. (UCID-20600).

Buddemeier, R. W., M. R. Ruggieri, and J.A. Oberdorfer (1987), Tritium in Groundwater at Site 300, Lawrence Livermore National Laboratory, Livermore, Calif. (UCID21031).

California Division of Mines and Geology(CDMG) (third printing, 1977), Geologic Map of California, San Francisco Sheet, Scale 1:250,000, California Division of Mines and Geology, Sacramento, Calif.

Carpenter, D. W., A. L. Lamarre, N. B. Crow, and P.M. Swearengen (1988), Closure Plan for the Decommissioned High Explosives Rinse-Water Lagoons at Lawrence Livermore National Laboratory Site 300, Lawrence Livermore National Laboratory, Livermore, Calif. (UCID21369).

Crow, N.B. and K.C. Toney (1991), Logs of Wells and Boreholes Drilled During Hydrogeologic studies at Lawrence Livermore National Laboratory Site 300: June 30, 1988 to January 1, 1991, Lawrence Livermore National Laboratory, Livermore, Calif. (UCID-21536, Addendum 1).

Crow, N.B. and W.L. McConihe (1993), Logs of Wells and Boreholes Drilled During Hydrogeologic studies at Lawrence Livermore National Laboratory site 300: January 1, 1992 to September 1, 1992, Lawrence Livermore National Laboratory, Livermore, Calif. (UCID21536, Addendum 2).

Dibblee, T. W., Jr. (1980), A Preliminary Map of the Midway Quadrangle, Alameda and San Joaquin Counties, California, Calif., United States Geologic Survey (Open-File Report, 80-535).

Dugan, W.R. and R.S. Mateik (1990), Geologic Map of sections $15,16,20,21,22,25,27,28,29,33$, and 33 , within Site 300 [1:7200], presented to D.W Carpenter, Lawrence Livermore National Laboratory. 
Hoffman, F. (1988), Fault Investigation at Pit 1, LLNL Site 300 , letter to Michael L. Higgins, Regional Water Quality Control Board - Central Valley Region, December 15,1988 .

Huey, A. S. (1948), Geology of the Tesla Quadrangle, Calif., California Division of Mines (Bulletin 140).

Raber, E., and D. W. Carpenter (Eds.) (1983), An Evaluation of the Hydrology and Groundwater Chemistry Associated with Landfills at LLNL's Site 300, Lawrence Livermore National Laboratory, Livermore, Calif. (UCRL-53416).

Raymond, L.A. (1969), the stratigraphy and structural Geology of the Northern Lone Tree Creek and Southern Tracy Quadrangles, California, M.S. Thesis, San Jose State College, San Jose, Calif., $143 \mathrm{p}$.

Ruggieri, M. R., D. W. Carpenter, A. L. Lamarre, J. A. Oberdorfer, M. J. Taffet, and N. B. Crow (1988), LLNL Site 300 Environmental Investigations Quarterly, March 31, 1988, Lawrence Livermore National Laboratory, Livermore, Calif. (UCAR-10194-88-1).

Spink Corporation, (1977), Unpublished scale 1-inch to 200 feet Maps of Northern Lawrence Livermore National Laboratory site 300 .

Toney, K. C., and N. B. Crow (1988), Logs of Wells and Boreholes Drilled During Hydrogeologic studies at Lawrence Livermore National Laboratory Site 300, June 1,1982 to June 30, 1988, Lawrence Livermore National Laboratory, Livermore, Calif. (UCID-21536).

Taffet, M. J., J.A. Oberdorfer, T.M. Carlson, W.R. Dugan, and R.S. Mateik (1990), Draft Remedial Investigation of the Building 850/East Firing Area, Lawrence Livermore National Laboratory Site 300, Lawrence Livermore National Laboratory, Livermore, Calif. (UCRL-ID104335).

Taffet, M.J. and J.A. Oberdorfer (1991), Draft Feasibility Study of the Building 850/East Firing Area, Lawrence Livermore National Laboratory Site 300, April 1991, Lawrence Livermore National Laboratory, Livermore, Calif. (UCRL-AR-107033). 
Webster-Scholten, C.P., Editor, (1994), Draft Site-Wide Remedial Investigation Report, Lawrence Livermore National Laboratory Site 300, East and west Firing Areas Study Area, March 1994, Lawrence Livermore National Laboratory, Livermore, Calif. (UCRL-AR108131DR) . 
Appendix

Exploratory Trench Logs 


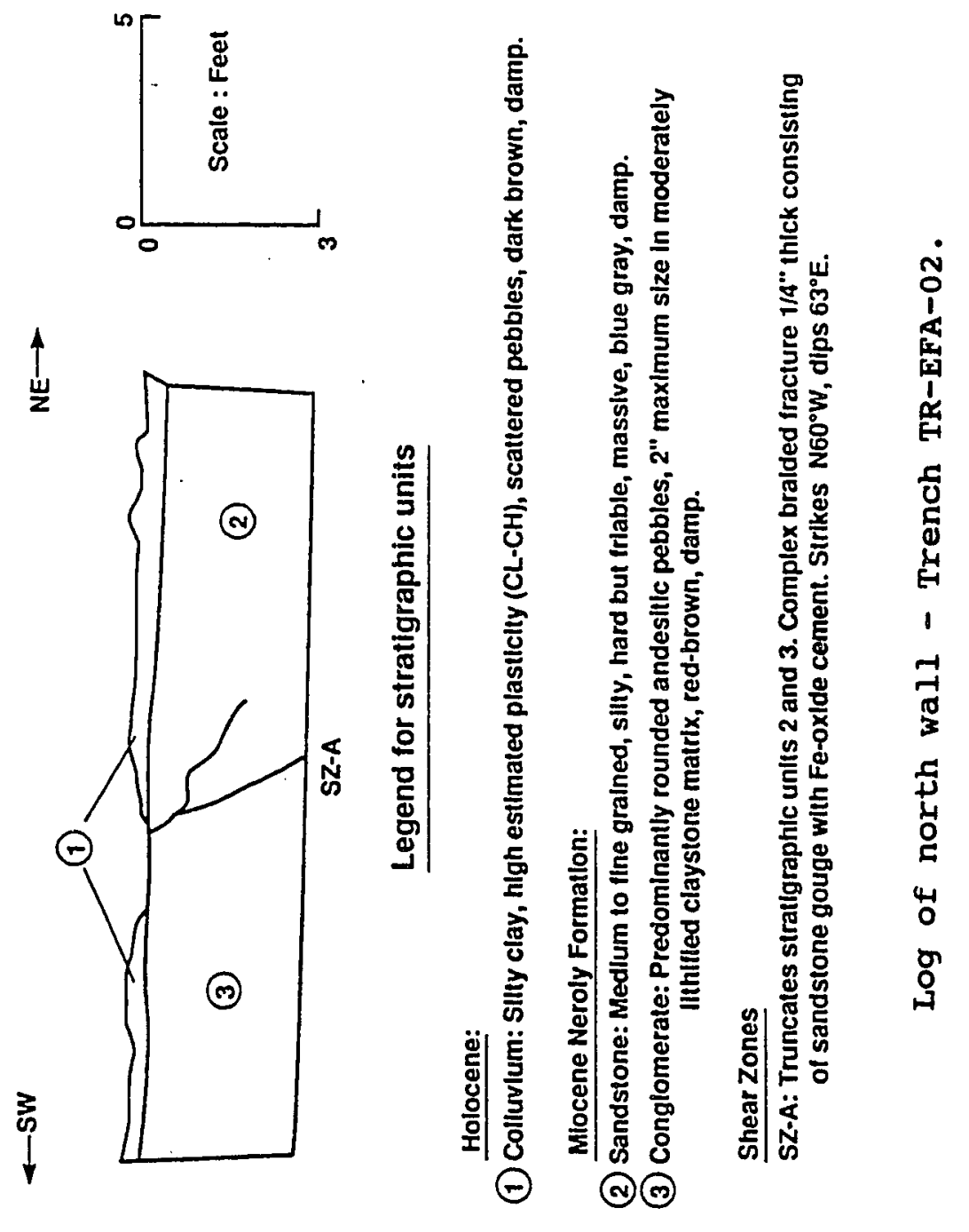




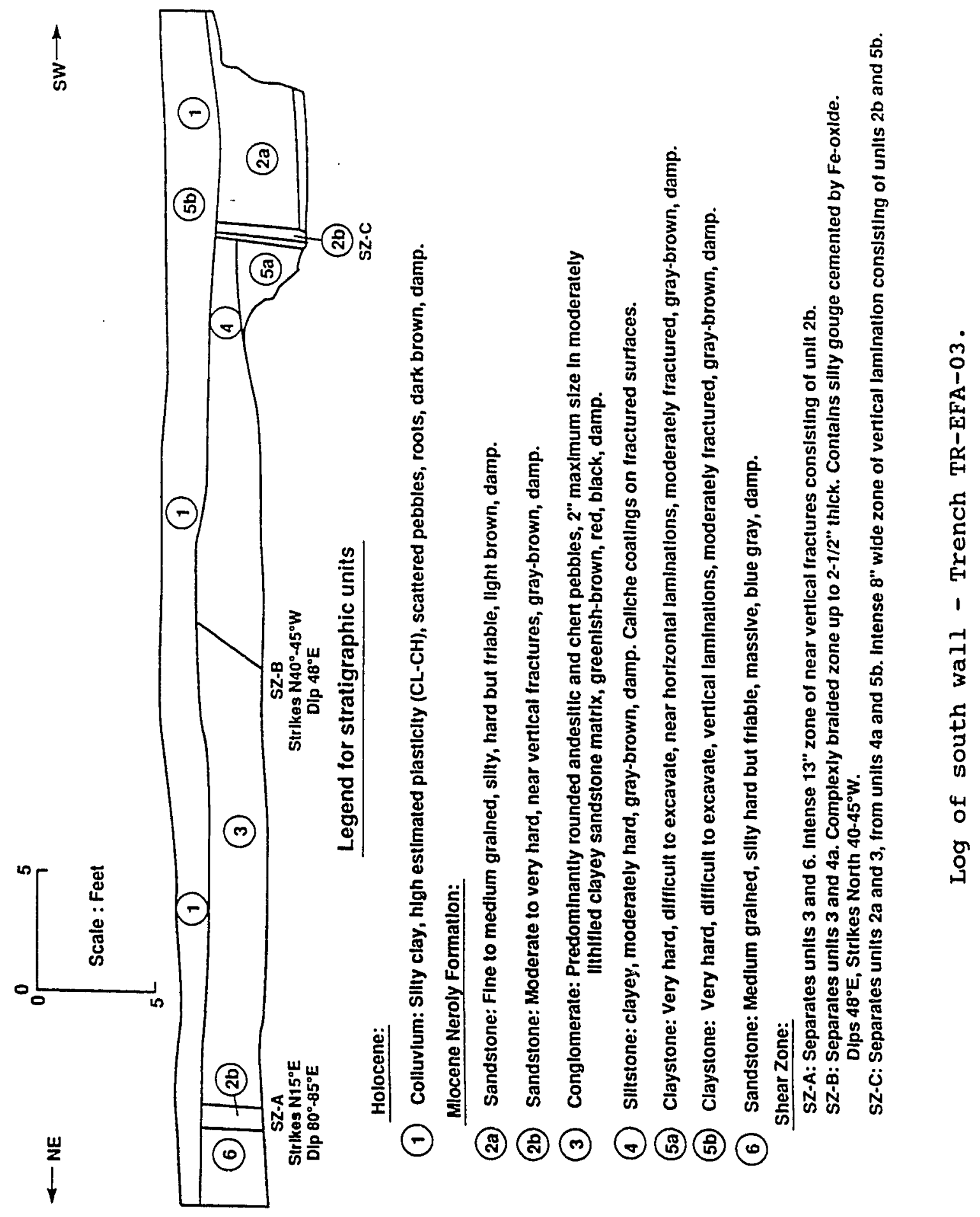




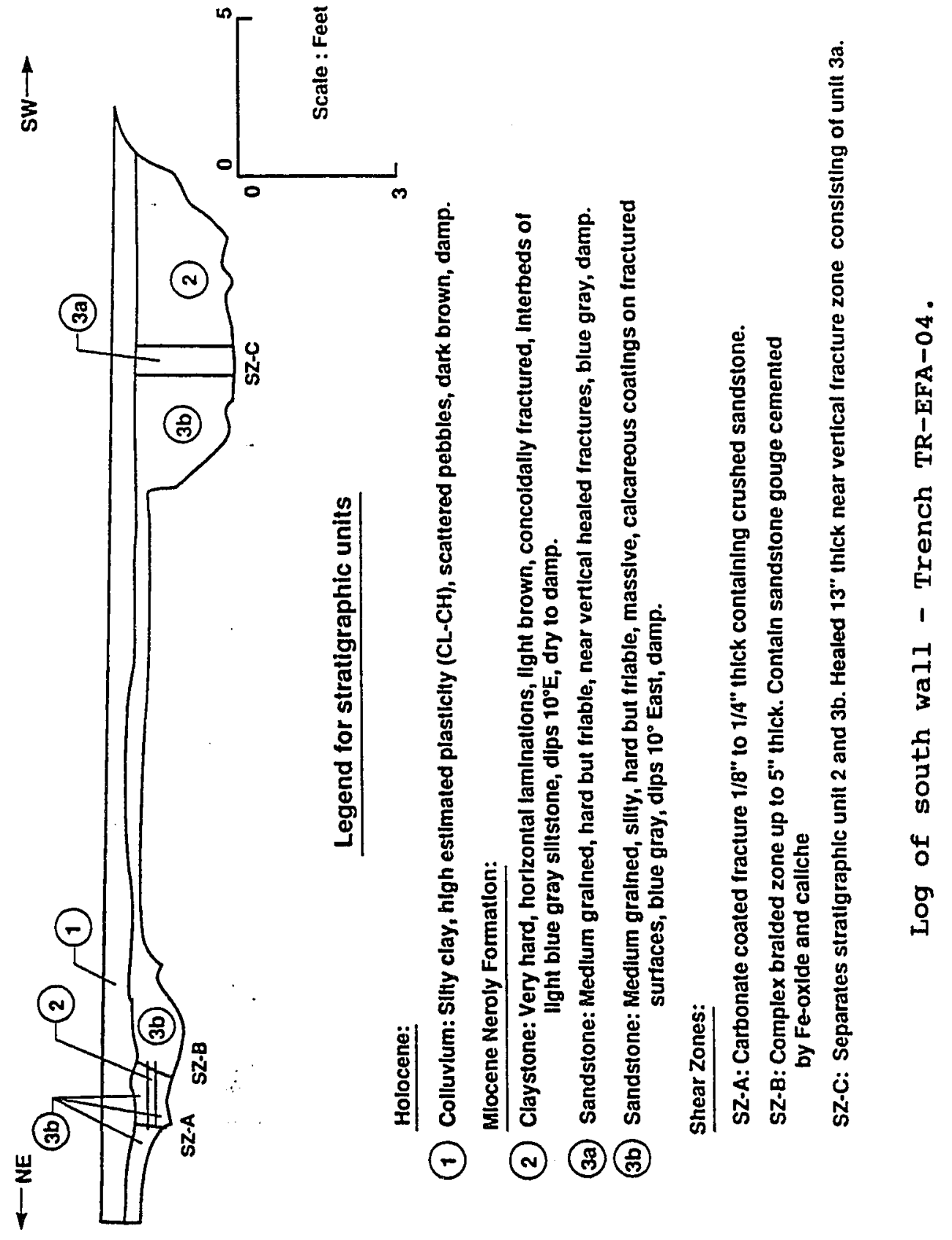




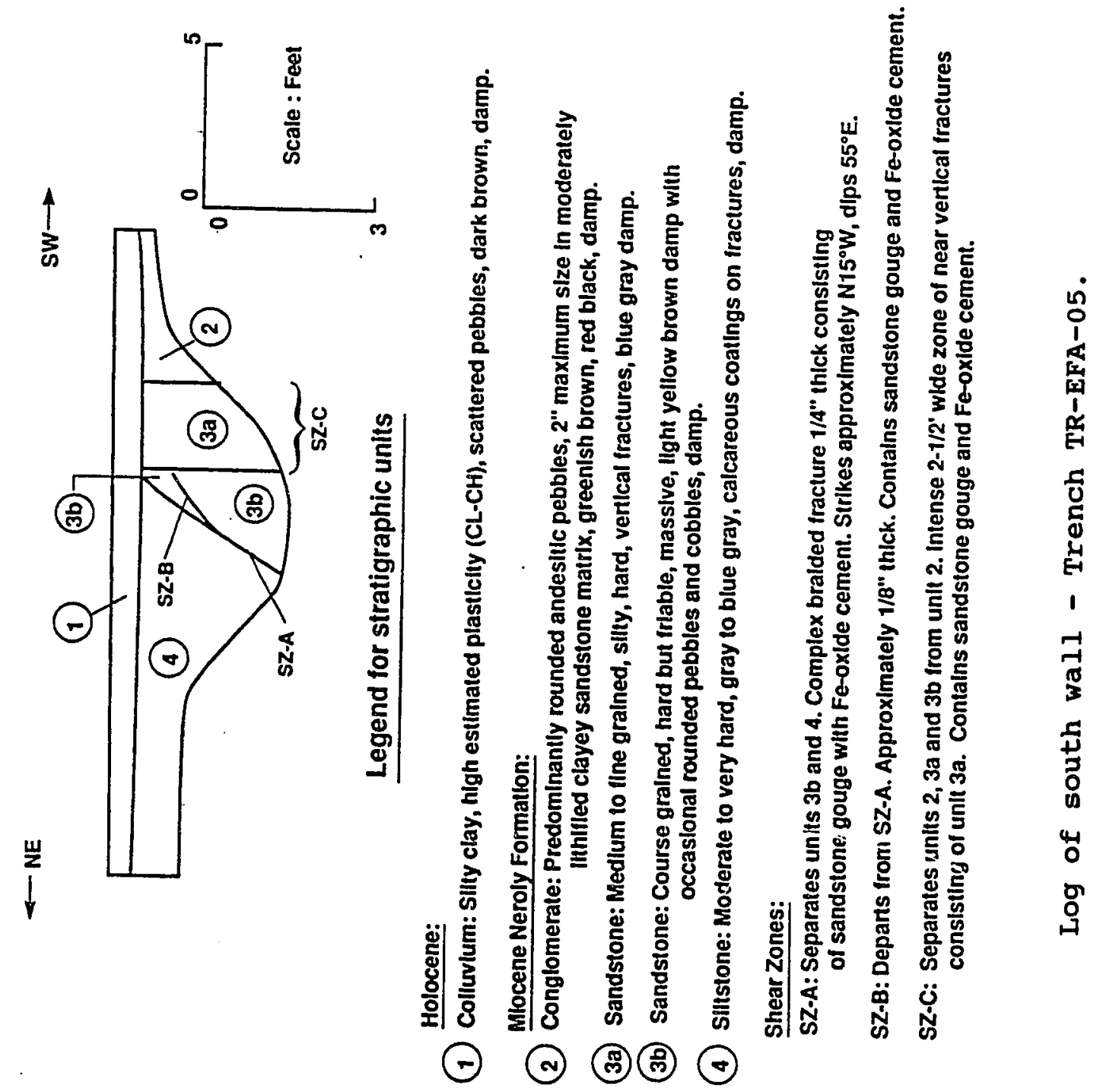

